\title{
Pathophysiology-based subphenotyping of individuals at elevated risk for type 2 diabetes
}

\author{
Robert Wagner ${ }^{1,2,3}$, Martin Heni ${ }^{1,2,3}$, Adam G. Tabak ${ }^{4,5,6}$, Jürgen Machann" ${ }^{2,7}$, Fritz Schick ${ }^{2,7}$, \\ Elko Randrianarisoa ${ }^{1,2}$, Martin Hrabě de Angelis ${ }^{2,8,9}$, Andreas L. Birkenfeld ${ }^{1,2,3}$, Norbert \\ Stefan $^{1,2,3,10}$, Andreas Peter ${ }^{1,2,11}$, Hans-Ulrich Häring ${ }^{1,2}$ and Andreas Fritsche ${ }^{1,2,3}$
}

1. Institute for Diabetes Research and Metabolic Diseases of the Helmholtz Center Munich at the University of Tübingen, Germany

2. German Center for Diabetes Research (DZD e.V.), Neuherberg, Germany

3. Department of Internal Medicine, Division of Diabetology, Endocrinology and Nephrology, Eberhard-Karls University Tübingen, Germany

4. Department of Epidemiology and Public Health, University College London, London, United Kingdom

5. Department of Internal Medicine and Oncology, Semmelweis University Faculty of Medicine, Budapest, Hungary

6. Department of Public Health, Semmelweis University Faculty of Medicine, Budapest, Hungary

7. University Department of Radiology, Section on Experimental Radiology, Eberhard-Karls

University Tübingen, Germany

8. Helmholtz Zentrum München, Institute of Experimental Genetics and German Mouse Clinic,

Neuherberg, Germany

9. Chair of Experimental Genetics, Centre of Life and Food Sciences, Weihenstephan, Technische Universität München, Freising, Germany

10. Department of Pediatrics, Harvard Medical School, Boston, MA, USA

11. Institute for Clinical Chemistry and Pathobiochemistry, Department for Diagnostic Laboratory Medicine, University Hospital of Tübingen, Germany

Present address:

Robert Wagner, Otfried-Müller-Str 10, 72076 Tübingen, Germany

Corresponding author: Robert Wagner

E-mail: robert.wagner@uni-tuebingen.de

NOTE: This preprint reports new research that has not been certified by peer review and should not be used to guide clinical practice. 
medRxiv preprint doi: https://doi.org/10.1101/2020.10.12.20210062; this version posted October 14, 2020. The copyright holder for this preprint (which was not certified by peer review) is the author/funder, who has granted medRxiv a license to display the preprint in It is made available under a CC-BY-NC-ND 4.0 International license

\section{Abstract}

The state of intermediate hyperglycemia is indicative of elevated risk of developing type 2 diabetes ${ }^{1}$. However, the current definition of prediabetes neither reflects subphenotypes of pathophysiology of type 2 diabetes nor is it predictive of future metabolic trajectories. We used partitioning on variables derived from oral glucose tolerance tests, MRI measured body fat distribution, liver fat content, and genetic risk in a cohort of extensively phenotyped individuals who are at increased risk for type 2 diabetes $^{2,3}$ to identify six distinct clusters of subphenotypes. Three of the identified subphenotypes have increased glycemia (clusters 3, 5 and 6), but only individuals in clusters 5 and 3 have immanent diabetes risks. By contrast, those in cluster 6 have moderate risk of type 2 diabetes, but an increased risk of kidney disease and all-cause mortality. Findings were replicated in an independent cohort using simple anthropomorphic and glycemic constructs ${ }^{4}$. This proof-of-concept study demonstrates that pathophysiological heterogeneity exists before diagnosis of type 2 diabetes and highlights a group of individuals who have an increased risk of complications without rapid progression to overt type 2 diabetes. 
medRxiv preprint doi: https://doi.org/10.1101/2020.10.12.20210062; this version posted October 14,2020 . The copyright holder for this preprint (which was not certified by peer review) is the author/funder, who has granted medRxiv a license to display the preprint in It is made available under a CC-BY-NC-ND 4.0 International license .

\section{Introduction}

Type 2 diabetes occurs when insulin secretion from pancreatic beta-cells cannot sufficiently be increased to compensate for insulin resistance. Causes of beta-cell dysfunction and insulin resistance are heterogeneous, as are individual trajectories of hyperglycemia and subsequent manifestation of diabetes complications ${ }^{5}$. The currently used binary definition of type 2 diabetes is based solely on blood glucose and cannot differentiate between patients with mild or more aggressive disease, the latter of which is prone to early development of complications. In addition to blood glucose, new proposed diabetes classifications ${ }^{6,7}$ introduced additional variables, such as insulin secretion and insulin sensitivity, to sub-classify the type 2 diabetes spectrum with the primary aim of a better prediction of metabolic dysfunction and complications. The development of type 2 diabetes is a slow process, and its manifestation is preceded by a phase of prediabetes which often remains undiagnosed. Some diabetes complications, such as the unexpectedly frequent early diabetic kidney disease in the newly identified severe insulin resistant diabetes cluster ${ }^{6}$, might require preventive actions prior to the clinical manifestation of type 2 diabetes. The assessment of insulin secretion and insulin sensitivity could be hindered by secondary gluco-lipotoxicity, once diabetes has developed and glucose levels are continuously elevated ${ }^{8}$. Determination of prediabetes subphenotypes prior to the manifestation of diabetes could improve detection of individuals at risk for diabetes and complications. Using accurate measurements of insulin sensitivity and insulin secretion based on oral glucose tolerance test (OGTT)-derived variables, as well as variables linked to diabetes pathogenesis, we describe a novel subphenotyping approach of metabolic risk before diabetes manifestation. Variables include HDL-cholesterol, which has been causally linked to type 2 diabetes $^{9}$, MR-imaging-derived measures of metabolically unfavorable and favorable fat compartments ${ }^{10}$ and liver fat content measured with ${ }^{1} \mathrm{H}-$ MR-spectroscopy. To assess genetic liability, we also incorporated a type 2 diabetes polygenic risk score ${ }^{11}$ as partitioning variable. The clusters identified by the sophisticated phenotypes in the TUEF/TULIP cohort were replicated using simpler markers of similar anthropometric and glycemic constructs in a large prospective occupational cohort (the Whitehall II study) ${ }^{4}$. Our results suggest that stratification of 
medRxiv preprint doi: https://doi.org/10.1101/2020.10.12.20210062; this version posted October 14, 2020. The copyright holder for this preprint (which was not certified by peer review) is the author/funder, who has granted medRxiv a license to display the preprint in It is made available under a CC-BY-NC-ND 4.0 International license.

populations at increased risk for type 2 diabetes using simple clinical features could allow for precise and efficient prevention strategies individuals at increased risk of developing type 2 diabetes. 
medRxiv preprint doi: https://doi.org/10.1101/2020.10.12.20210062; this version posted October 14,2020 . The copyright holder for this preprint (which was not certified by peer review) is the author/funder, who has granted medRxiv a license to display the preprint in It is made available under a CC-BY-NC-ND 4.0 International license .

\section{Results}

Initial clustering and identification of the subphenotypes was done using data from a subset of participants $(\mathrm{n}=899)$ from the Tuebingen Family study and Tuebingen Lifestyle Program (TUEF/TULIP) study. Analysis was performed on data for participants who had no missing values for the preselected phenotyping variables: glucose challenge; insulin sensitivity; insulin secretion; HDL-cholesterol; liver fat content; subcutaneous fat volume; visceral fat volume; and a polygenic risk score for type 2 diabetes risk The clustering was replicated in the Whitehall II cohort $(n=6810)$ using conceptually similar variables: glycemia during glucose challenge, insulin sensitivity, insulin secretion, fasting insulin, fasting triglycerides, waist circumference, hip circumference, BMI and HDL-cholesterol (Extended Data 1; see Methods). We identified six clusters with distinctive patterns of the variables in the TUEF/TULIP study (Figure 1.A,B), which were replicated in the Whitehall II cohort (Figure 1 C,D). Cluster characteristics and comparisons are shown in Table 1, Suppl.Table 1-3 and key features of the clusters are reported in Extended Data 2.

There was a cluster-specific enrichment of the diabetes-related genetic variant rs10830963 in MTNR1B (ANOVA p=0.02 after Benjamini-Hochberg correction for multiple testing, Suppl.Table 4). Participants in cluster 3 had higher frequency of the diabetes-associated $\mathrm{G}$ allele compared with those in cluster 1 (uncorrected $\mathrm{p}=0.00036$ for cluster 3 relative to cluster 1 ). Using the pathophysiological classification of diabetes-related genetic variants proposed by Udler et $\mathrm{al}^{12}$, we found differences within the beta-cell group (uncorrected $\mathrm{p}=0.001$, $\mathrm{p}=0.007$ after Benjamini-Hochberg correction, Figure 2.A). Pairwise comparisons showed significant differences between cluster 6 and each of clusters 1, 2 and 3 (ANOVA with Tukey's post-hoc test $\mathrm{p}<0.05$ ), suggesting a lower abundance of betacell function related risk alleles in cluster 6 .

In the longitudinal analysis, all participants with available data were followed for the development of diabetes, nephropathy, cardiovascular endpoints and all-cause mortality (Figure 3). The proportional hazards assessment in Whitehall II is shown in 
medRxiv preprint doi: https://doi.org/10.1101/2020.10.12.20210062; this version posted October 14,2020 . The copyright holder for this preprint (which was not certified by peer review) is the author/funder, who has granted medRxiv a license to display the preprint in It is made available under a CC-BY-NC-ND 4.0 International license .

Suppl.Table 5. Diabetes incidence was the highest in cluster 5, followed by cluster 3 in both the TUEF/TULIP and Whitehall-II cohorts. Mean follow-up was 4.1 and 16.3 years, respectively. In TUEF/TULIP, participants in cluster 6 did not demonstrate an increased risk for diabetes (Figure 3.A). The diabetes-risk of cluster 6 was only moderately elevated in Whitehall II (HR 2.22[CI:1.7-2.89] compared with cluster 1. Cluster 3 and 5 showed hazard ratios of 3.45[CI:2.76-4.31] and 6.62[CI:5.06-8.67], respectively, compared with cluster 1, (Figure 3.C, Suppl.Table 5). By contrast, cluster 2 had a significantly lower risk of developing diabetes in the Whitehall II cohort compared with cluster 1 (HR 0.4[CI:0.33-0.47]). Current smoking was a risk factor for diabetes in Whitehall II, but did not affect the risk of diabetes for participants in clusters 3, 5 and 6 (Suppl.Table 6).

In Whitehall II, there were 201 participants with incident diabetes and a defined Ahqlvist diabetes classification ${ }^{6}$. Relatively few participants developed diabetes in the metabolically healthy clusters (cluster 1: 48 of 817 [5.9\%], cluster 2: 62 of 2552 [2.4\%], cluster $4: 14$ of 314 [4.5\%], out of those eligible for computation of the Ahlqvist-classes). Of these participants, most (34 of 48 [70.8\%], 59 of 62 [95.2\%] and 12 of 14 [85.7\%], respectively) transitioned into mild diabetes classes according to the Ahlqvist-classification (mild obesity-related diabetes [MOD] and mild age-related diabetes [MARD]). 13 of 23 participants (57\%) in cluster 6 (13 of 23 [57\%]) developed severe insulin resistant diabetes (SIRD, Suppl.Table 7 and Extended Data $3)$.

We used two approaches to compare our multivariable clustering with glucose-based stratification alone. We first tested cumulative diabetes risk for the Hulman classes ${ }^{13}$ that are computed from the glucose course during an OGTT (Extended Data 4). Next, we stratified the baseline AUC glucose of Whitehall II into 5 quintiles, (Extended Data 5). In head-to-head comparisons, the cumulative diabetes risk of the high risk clusters 3 and 5 together was higher than that of Hulman-classes 3 and 4 together $(p=0.04$, TUEF/TULIP) and also higher than that of the top 2 AUC glucose quintiles $(p<0.0001$, Whitehall II, both log-rank tests). Thus, our cluster-based approach was superior to both of these approaches in delineating groups with high cumulative risk for development of diabetes. 
medRxiv preprint doi: https://doi.org/10.1101/2020.10.12.20210062; this version posted October 14,2020 . The copyright holder for this preprint (which was not certified by peer review) is the author/funder, who has granted medRxiv a license to display the preprint in It is made available under a CC-BY-NC-ND 4.0 International license .

The overall difference in the Kaplan-Meier curves for microalbuminuria did not reach statistical significance in TUEF/TULIP (mean follow-up 4.3 years, number of events $=71$, $p_{\text {log-rank, uncorrected }}=0.061$, Figure $\left.3 . B\right)$. In the proportional hazard assessment, cluster 6 showed a significantly higher risk for microalbuminuria compared with cluster $1(\mathrm{p}=0.01)$. Results were similar but not significant for the Whitehall II participants with available baseline urine measurements $(n=316$, number of events $=58$, uncorrected $\mathrm{p}=0.058$ ) when adjusting for baseline urinary albumin-to-creatinine ratio. In Whitehall II, participants in cluster 6 had a significantly higher risk for stage 3 chronic kidney disease or worse than cluster 1 (uncorrected $\mathrm{p}=0.0003$, mean follow-up 18.2 years, number of events 1387, Figure 3.D, Extended Data 6). Individuals in the diabetes susceptible clusters 3 and 5 also demonstrated higher risks for chronic kidney disease relative to cluster 1 in Whitehall II (uncorrected $p=0.004$ and $p=0.02$, respectively, Suppl.Table 5). The fully adjusted model also controlled for smoking, cholesterol and triglycerides is shown in Suppl.Table 8. Given that participants in cluster 6 had elevated visceral fat, we hypothesized that this could be associated with fat in the renal sinuses, which is a risk factor for exercise-induced microalbuminuria ${ }^{14}$. TUEF/TULIP participants in cluster 6 had the most renal sinus fat compared with other clusters $(\mathrm{p}<0.05$ for all pairwise comparisons, Tukey's post-hoc test, Figure 2.B, $\mathrm{N}=199$ ). It was higher than in cluster 5 after adjusting for potential confounders (Suppl.Table 9.A-D).

In the TUEF/TULIP cohort, we used carotid intima media thickness (IMT) as a proxy for cardiovascular end-points due to a lack of a register-based assessment of clinical events. IMT was associated with cluster membership $(\mathrm{F}=14.55$, degrees of freedom $=5$, $\mathrm{p}<0.001)$. Each of clusters 3, 5 and 6 had higher IMT values than each of clusters 1,2 or 4 (Extended Data 7 and Suppl.Table 1, p<0.002). After adjustment for sex, age, age ${ }^{2}$ and BMI, cluster 3 and 5 had higher IMT than cluster $1(\mathrm{p}<0.03)$. In the Whitehall II cohort, we evaluated the incidence of coronary heart disease (CHD, mean follow-up 17.2 years, 800 events, see Figure 2.E). As a combined vascular endpoint, we also investigated the incidence of CHD and stroke (mean follow-up 22.9 years, 1040 events, Suppl.Table 5). In the proportional hazard assessment, the elevated cardiovascular risk in cluster 5 was not independent from sex, age and BMI, but 
medRxiv preprint doi: https://doi.org/10.1101/2020.10.12.20210062; this version posted October 14, 2020. The copyright holder for this preprint (which was not certified by peer review) is the author/funder, who has granted medRxiv a license to display the preprint in It is made available under a CC-BY-NC-ND 4.0 International license.

consistently lower in cluster 2 compared with cluster 1 , also after adjustments (Suppl.Table 5). Compared with cluster 1 in Whitehall II, all-cause mortality was by about $40 \%$ higher for cluster 6 (Figure 3.F), while cluster 2 had a lower mortality rate, even after adjustments for covariates (Suppl.Table 5). The elevated mortality risk in cluster 6 (relative to cluster 1) was not affected by adjustment for smoking and lipids (full model in Suppl.Table 10). 
medRxiv preprint doi: https://doi.org/10.1101/2020.10.12.20210062; this version posted October 14,2020 . The copyright holder for this preprint (which was not certified by peer review) is the author/funder, who has granted medRxiv a license to display the preprint in It is made available under a CC-BY-NC-ND 4.0 International license .

\section{Discussion}

The applied variable-based partitioning of individuals without type 2 diabetes yielded groups differing in risk for type 2 diabetes and its complications. We validated these findings using simple measures of the same pathophysiological constructs in a large occupational cohort.

Cluster 5 was identified as the subpopulation of the highest risk of type 2 diabetes, renal and vascular disease and all-cause mortality. Individuals in this cluster had obesity, insulin resistance, high levels of fatty liver and low insulin secretion. Cluster 6 represented an insulin resistant phenotype, in which participants had high amounts of visceral fat, but less liver fat and higher insulin secretion compared with cluster 5 . About half of the participants in cluster 6 had prediabetes on enrollment in the TUEF/TULIP study. However, mean glycemia (AUC glucose) was lower than in cluster 5, and the risk of type 2 diabetes was considered to be moderate. Nonetheless, participants in cluster 6 had high risk for microalbuminuria and chronic kidney disease. Cardiovascular risk was not elevated in this cluster; however, overall mortality was about $40 \%$ higher than in the reference cluster 1 even after adjustment for confounders. Thus, clusters 5 and 6 both constitute obese, high-risk subpopulations with different glycemic, renal, cardiovascular and all-cause mortality risk profiles. Glucose does not seem to be the major driver of clinical events in cluster 6. Previous observations of an association of insulin resistance with diabetic nephropathy ${ }^{15-17}$ highlight insulin resistance as a probable underlying factor. The discrepancy between moderate type 2 diabetes and high nephropathy risk for cluster 6 is not dependent from baseline blood pressure. However, individuals in cluster 6 had elevated renal sinus fat, which could contribute to manifestation of nephropathy. We previously showed an association between renal sinus fat and exercise-induced albuminuria in a crosssectional cohort and an association of microalbuminuria with renal sinus fat in individuals with non-alcoholic fatty liver disease ${ }^{14,18}$. In renal sinus fat and renal cell co-culture experiments, the combination of renal sinus fat and Fetuin-A induced inflammation indicate a combination of an insulin resistant metabolic milieu and adverse fat accumulation as a likely cause of organ damage ${ }^{18}$. This finding is consistent with the phenotypes of insulin resistance, moderately high liver fat and high 
medRxiv preprint doi: https://doi.org/10.1101/2020.10.12.20210062; this version posted October 14,2020 . The copyright holder for this preprint (which was not certified by peer review) is the author/funder, who has granted medRxiv a license to display the preprint in It is made available under a CC-BY-NC-ND 4.0 International license .

renal sinus fat in cluster 6 . Cluster 6 , in which participants had moderate or delayed risk of diabetes, showed a relatively low genetic risk for type 2 diabetes and a low abundance of genetic variants from the beta-cell class in the Udler classification ${ }^{12}$. This result implies an effective compensation of insulin resistance through excellent beta-cell function. We speculate that hyperinsulinemia associated with the combination of good beta-cell function and insulin resistance contributes to renal disease and mortality ${ }^{19-21}$. Smoking was a risk factor both for diabetes and chronic kidney disease $\mathrm{e}^{22-24}$, but did not explain the differences among clusters.

Contrast to the three high-risk clusters 3,5 and 6, cluster 4 comprises participants with obesity but low glycemic deterioration. Phenotypic traits of individuals in this cluster are compatible with the concept of metabolically healthy obesity ${ }^{25}$. Cluster 4 was also associated with lower risk of type 2 diabetes, independently from sex, age, and BMI. Individuals in this cluster had body fat predominantly stored in subcutaneous rather than visceral depots, a pattern known to be metabolically more favorable ${ }^{26}$. In cluster 3, the partitioning identified a phenotype characterized by elevated genetic risk and low insulin secretion, which might explain the high diabetes incidence seen in this group. The moderately elevated visceral fat compartment correlates with pancreatic fat, which has been associated with disturbed insulin secretion in a prediabetic environment ${ }^{18,27,28}$. Cluster 3 with a disposition index as low as cluster 5, but higher insulin sensitivity could correspond to beta-cell dysfunction subphenotypes identified in previous studies ${ }^{6,7,29}$. Cluster 3 had high IMT, independent from sex, age and BMI. Increased cardiovascular risk was not replicated for this cluster in Whitehall II, but individuals in this cluster had a moderately elevated risk of chronic kidney disease.

Our clustering approach is not designed to provide definitive subphenotypes for individual patients in a clinical setting; however, the approach can be helpful for characterizing the metabolic heterogeneity prior to clinical manifestation of type 2 diabetes. The identification of such subphenotypes suggests some potential therapeutic implications. Individuals in cluster 5 are at imminent risk for diabetes and could benefit from high intensity dietary and/or lifestyle interventions aimed at weight loss and liver fat reduction. Individuals with the characteristics of cluster 3 might benefit 
medRxiv preprint doi: https://doi.org/10.1101/2020.10.12.20210062; this version posted October 14,2020 . The copyright holder for this preprint (which was not certified by peer review) is the author/funder, who has granted medRxiv a license to display the preprint in It is made available under a CC-BY-NC-ND 4.0 International license .

from a standard aerobic exercise and dietary caloric restriction via reduction of visceral fat. Although clusters 3 and 5 have elevated genetic risk as non-modifiable risk factor, genetic predisposition might be protective against development of type 2 diabetes for individuals with a cluster 6 phenotype. This group could be easily overlooked when risk-stratification focuses on established diabetes-related glycemic cut-offs. Insulin resistance with or without prevalent prediabetes associates with renal disease and elevated mortality in cluster 6 , which should motivate consideration of preventive measures even with low glycemic progression.

Our subphenotyping was performed in persons who did not yet suffer from diabetes, but who are at potentially increased risk, as demonstrated by the newly diagnosed cases in the follow-up period. The classification emerges partly from variables that require an OGTT. OGTT-derived glycemic traits can reasonably assess insulin sensitivity and secretion, particularly in the absence of diabetes. An elegant metabolic clustering of glycemic courses during OGTT has been proposed by Hulman et $\mathrm{al}^{13}$. We have applied an alternative approach with a broad set of variables in addition to OGTT. Our data complement other clustering approaches targeting the disentanglement of the heterogeneity of adult-onset diabetes ${ }^{6,7,12}$. We show that cluster 6 most strongly connects to the SIRD cluster of the Ahlqvist-classification ${ }^{6,30}$. Cluster 6 and SIRD bear similarities, such as an elevated risk of nephropathy in the absence of marked glucose elevation. Thus, accumulating data indicate that the pathogenesis of kidney damage in type 2 diabetes appears to be different from that of type 1 diabetes, with only a minor contribution of glycaemia in prediabetes and type 2 diabetes. Of note, by contrast with the Ahlqvist-classification, our work analyzed screen-detected diabetes cases as outcomes during the follow-up periods. These cases probably have milder phenotypes than clinically detected type 2 diabetes cases.

Our results are demonstrated in two independent study groups: a cohort by design enriched in diabetes-prone persons and a UK occupational cohort. This most likely contributes to the observed differences between the Kaplan-Meier plots in the two cohorts, especially for diabetes incidence. Given the lack of ethnic diversity of the investigated populations leveraged in our study, our findings might only be applicable to white European populations. We also acknowledge the limitations of the partitioning approach: there is uncertainty with regard to variable selection, the 
medRxiv preprint doi: https://doi.org/10.1101/2020.10.12.20210062; this version posted October 14, 2020. The copyright holder for this preprint (which was not certified by peer review) is the author/funder, who has granted medRxiv a license to display the preprint in It is made available under a CC-BY-NC-ND 4.0 International license

optimal number of clusters and whether these approaches are inferior to conventional predictions from multivariable modeling ${ }^{29}$. Additional specific limitations of our work are the different feature variable set and the moderate reassignment rate $(63 \%)$ of the original clusters to the feature set of Whitehall II. Given the sophisticated nature of the variables in TUEF/TULIP cohort, the clinical utility of these features for metabolic classification could be limited. Further, in the TUEF/TULIP cohort, only about half of the population was available for follow-up visits. This high attrition rate could lead to a potential underestimation of the risk for diabetes and nephropathy in the TUEF/TULIP cohort. A final limitation is that the nephropathy models in Whitehall II are not adjusted for baseline eGFR due to a lack of baseline measurements and the absolute risks being low.

In summary, we show the feasibility of multi-variable subphenotyping in individuals without diabetes to disentangle metabolic heterogeneity prior to diagnosis of type 2 diabetes. The metabolic clusters identified here associate with future complications related to prediabetes, insulin resistance, future risk of type 2 diabetes and mortality. These subphenotypes likely reflect key pathologic features potentially underlying different fates of metabolic complications but are not aimed at classifying single patients in clinical practice; however, with further development and validation, such approaches could guide prevention and treatment strategies for cardiovascular and renal disease as well as type 2 diabetes. 
medRxiv preprint doi: https://doi.org/10.1101/2020.10.12.20210062; this version posted October 14, 2020. The copyright holder for this preprint (which was not certified by peer review) is the author/funder, who has granted medRxiv a license to display the preprint in It is made available under a CC-BY-NC-ND 4.0 International license

\section{Acknowledgments}

We thank all the research volunteers for their participation. We thank all participants in the Whitehall II Study, Whitehall II researchers and support staff who made the study possible. We gratefully acknowledge the excellent technical assistance of the Diabetes Research Unit Diabetes Research and Metabolic Diseases of the Helmholtz Center Munich at the University of Tübingen, Germany.

We thank J. Kriebel and H. Grallert (Molecular Epidemiology, Helmholtz Center Munich) for generating the Global Screening Array data. This study was supported in parts by a grant (01GI0925) from the Federal Ministry of Education and Research (BMBF) to the German Center for Diabetes Research (DZD e.V.) and from the state of Baden-Württemberg to RW and AF (32-5400/58/2, Forum Gesundheitsstandort Baden-Württemberg). The UK Medical Research Council (MR/K013351/1; G0902037), British Heart Foundation (RG/13/2/30098), and the US National Institutes of Health (R01HL36310, R01AG013196) have supported collection of data in the Whitehall II Study.

\section{Author contributions}

R.W. analyzed the data and wrote the manuscript. M.H., A.G.T., J.M., F.S., E.R., A.F. contributed to data acquisition, the interpretation of data and edited the manuscript. M.H.A., A.P. A.L.B and N.S contributed to the interpretation of data and edited the manuscript. H-U.H. and A.F. contributed to the concept of the work and edited the manuscript. All authors have reviewed the manuscript.

\section{Competing Interests Statement}

We declare that none of the authors have competing financial or non-financial interests as defined by Nature Research 
medRxiv preprint doi: https://doi.org/10.1101/2020.10.12.20210062; this version posted October $14,2020$. The copyright holder for this preprint (which was not certified by peer review) is the author/funder, who has granted medRxiv a license to display the preprint in It is made available under a CC-BY-NC-ND 4.0 International license .

\section{References}

1. Tabák, A. G., Herder, C., Rathmann, W., Brunner, E. J. \& Kivimäki, M.

Prediabetes: a high-risk state for diabetes development. Lancet 379, 2279-2290 (2012).

2. Stumvoll, M. et al. Association of the T-G polymorphism in adiponectin (exon 2) with obesity and insulin sensitivity: interaction with family history of type 2 diabetes. Diabetes 51, 37-41 (2002).

3. Schmid, V. et al. Non-alcoholic fatty liver disease and impaired proinsulin conversion as newly identified predictors of the long-term non-response to a lifestyle intervention for diabetes prevention: results from the TULIP study. Diabetologia (2017) doi:10.1007/s00125-017-4407-z.

4. Marmot, M. \& Brunner, E. Cohort Profile: the Whitehall II study. Int J Epidemiol 34, 251-256 (2005).

5. Davidson, M. B. Diagnosing Diabetes With Glucose Criteria: Worshipping a False God. Diabetes Care 34, 524-526 (2011).

6. Ahlqvist, E. et al. Novel subgroups of adult-onset diabetes and their association with outcomes: a data-driven cluster analysis of six variables. The Lancet Diabetes \& Endocrinology $\mathbf{0},(2018)$.

7. Stidsen, J. V. et al. Pathophysiology-based phenotyping in type 2 diabetes: A clinical classification tool. Diabetes/Metabolism Research and Reviews $\mathbf{0}$, e3005 (2018).

8. Unger, R. \& Grundy, S. Hyperglycaemia as an inducer as well as a consequence of impaired islet cell function and insulin resistance: implications for the management of diabetes. (1985). 
medRxiv preprint doi: https://doi.org/10.1101/2020.10.12.20210062; this version posted October $14,2020$. The copyright holder for this preprint (which was not certified by peer review) is the author/funder, who has granted medRxiv a license to display the preprint in It is made available under a CC-BY-NC-ND 4.0 International license .

9. O’Connor, L. J. \& Price, A. L. Distinguishing genetic correlation from causation across 52 diseases and complex traits. Nature Genetics 1 (2018) doi:10.1038/s41588-018-0255-0.

10. Stefan, N., Schick, F. \& Häring, H.-U. Causes, Characteristics, and Consequences of Metabolically Unhealthy Normal Weight in Humans. Cell Metabolism 26, 292300 (2017).

11. Mahajan, A. et al. Refining the accuracy of validated target identification through coding variant fine-mapping in type 2 diabetes. Nature Genetics 50, 559 (2018).

12. Udler, M. S. et al. Type 2 diabetes genetic loci informed by multi-trait associations point to disease mechanisms and subtypes: A soft clustering analysis. PLoS Med. 15, e1002654 (2018).

13. Hulman, A. et al. Pathophysiological Characteristics Underlying Different Glucose Response Curves: A Latent Class Trajectory Analysis From the Prospective EGIRRISC Study. Diabetes Care dc180279 (2018) doi:10.2337/dc18-0279.

14. Wagner, R. et al. Exercise-induced albuminuria is associated with perivascular renal sinus fat in individuals at increased risk of type 2 diabetes. Diabetologia $\mathbf{5 5}$, 2054-2058 (2012).

15. DeFronzo, R. A. \& Ferrannini, E. Insulin Resistance: A Multifaceted Syndrome Responsible for NIDDM, Obesity, Hypertension, Dyslipidemia, and Atherosclerotic Cardiovascular Disease. Diabetes Care 14, 173-194 (1991).

16. Yip, J. et al. Insulin resistance in insulin-dependent diabetic patients with microalbuminuria. The Lancet 342, 883-887 (1993). 
medRxiv preprint doi: https://doi.org/10.1101/2020.10.12.20210062; this version posted October 14,2020 . The copyright holder for this preprint (which was not certified by peer review) is the author/funder, who has granted medRxiv a license to display the preprint in It is made available under a CC-BY-NC-ND 4.0 International license .

17. Parvanova, A. I. et al. Insulin resistance and microalbuminuria: a cross-sectional, case-control study of 158 patients with type 2 diabetes and different degrees of urinary albumin excretion. Diabetes 55, 1456-1462 (2006).

18. Gerst, F. et al. Metabolic crosstalk between fatty pancreas and fatty liver: effects on local inflammation and insulin secretion. Diabetologia 1-12 (2017) doi:10.1007/s00125-017-4385-1.

19. El-Atat, F. A., Stas, S. N., McFarlane, S. I. \& Sowers, J. R. The Relationship between Hyperinsulinemia, Hypertension and Progressive Renal Disease. JASN 15, 2816-2827 (2004).

20. Ausk, K. J., Boyko, E. J. \& Ioannou, G. N. Insulin Resistance Predicts Mortality in Nondiabetic Individuals in the U.S. Diabetes Care 33, 1179-1185 (2010).

21. Artunc, F. et al. The impact of insulin resistance on the kidney and vasculature. Nat Rev Nephrol 12, 721-737 (2016).

22. Wannamethee, S. G., Shaper, A. G., Perry, I. J. \& British Regional Heart Study. Smoking as a modifiable risk factor for type 2 diabetes in middle-aged men. Diabetes Care 24, 1590-1595 (2001).

23. Hogan, S. L. et al. Association of Cigarette Smoking with Albuminuria in the United States: The Third National Health and Nutrition Examination Survey. Renal Failure 29, 133-142 (2007).

24. Cirillo, M. et al. Microalbuminuria in nondiabetic adults: relation of blood pressure, body mass index, plasma cholesterol levels, and smoking: The Gubbio Population Study. Arch. Intern. Med. 158, 1933-1939 (1998).

25. Stefan, N. et al. Identification and characterization of metabolically benign obesity in humans. Arch. Intern. Med. 168, 1609-1616 (2008). 
medRxiv preprint doi: https://doi.org/10.1101/2020.10.12.20210062; this version posted October 14, 2020. The copyright holder for this preprint (which was not certified by peer review) is the author/funder, who has granted medRxiv a license to display the preprint in It is made available under a CC-BY-NC-ND 4.0 International license

26. Stefan, N., Häring, H.-U. \& Schulze, M. B. Metabolically healthy obesity: the lowhanging fruit in obesity treatment? Lancet Diabetes Endocrinol 6, 249-258 (2018).

27. Heni, M. et al. Pancreatic fat is negatively associated with insulin secretion in individuals with impaired fasting glucose and/or impaired glucose tolerance: a nuclear magnetic resonance study. Diabetes Metab. Res. Rev. 26, 200-205 (2010).

28. Jaghutriz, B. A. et al. Metabolomic Characteristics of Fatty Pancreas. Exp. Clin. Endocrinol. Diabetes (2019) doi:10.1055/a-0896-8671.

29. Dennis, J. M., Shields, B. M., Henley, W. E., Jones, A. G. \& Hattersley, A. T. Disease progression and treatment response in data-driven subgroups of type 2 diabetes compared with models based on simple clinical features: an analysis using clinical trial data. The Lancet Diabetes \& Endocrinology 0, (2019).

30. Zaharia, O. P. et al. Risk of diabetes-associated diseases in subgroups of patients with recent-onset diabetes: a 5-year follow-up study. Lancet Diabetes Endocrinol 7, 684-694 (2019). 
medRxiv preprint doi: https://doi.org/10.1101/2020.10.12.20210062; this version posted October 14, 2020. The copyright holder for this preprint (which was not certified by peer review) is the author/funder, who has granted medRxiv a license to display the preprint in It is made available under a CC-BY-NC-ND 4.0 International license. 
medRxiv preprint doi: https://doi.org/10.1101/2020.10.12.20210062; this version posted October 14, 2020. The copyright holder for this preprint (which was not certified by peer review) is the author/funder, who has granted medRxiv a license to display the preprint in It is made available under a CC-BY-NC-ND 4.0 International license.

\section{Figure legends}

\section{Figure 1. Distribution of the cluster feature variables}

Partitioning of participants into 6 clusters along 8 variables in the TUEF/TULIP $(\mathrm{N}=899$, Panel $\mathbf{a}, \mathbf{b})$ and 9 variables in the Whitehall-II cohort $(\mathrm{N}=6810$, Panel $\mathbf{c}, \mathbf{d})$. Panel a and $\mathbf{c}$ show the number of participants in each cluster with colors indicating glycemic categories $(\mathrm{NGT}=$ normal glucose tolerance, $\mathrm{IFG}=$ impaired fasting glycaemia, IGT = impaired glucose tolerance, IFG+IGT concomitant impaired fasting glycaemia and impaired glucose tolerance). Panel $\mathbf{b}$ and $\mathbf{d}$ show the medoids (the representative subject, TUEF/TULIP) or the medians (Whitehall-II) of each cluster with the corresponding standardized level (Z-scores) of the feature variables. Clusters in the Whitehall-II cohort were identified using Euclidean distances from the median values of the proxy variables in TUEF/TULIP that have also been assessed in Whitehall-II. For the radar-charts $(\mathbf{b}, \mathbf{d})$, the Z-scores of insulin sensitivity, insulin secretion and HDL were directionally flipped $(-1 * Z$-score) to yield polygon areas related to adverse variable effects. 
medRxiv preprint doi: https://doi.org/10.1101/2020.10.12.20210062; this version posted October 14, 2020. The copyright holder for this preprint (which was not certified by peer review) is the author/funder, who has granted medRxiv a license to display the preprint in It is made available under a CC-BY-NC-ND 4.0 International license.

\section{Figure 2. Characteristics potentially contributing to cluster pathomechanism}

a, Mean pathway-specific genetic scores according to Udler et al across the 6 clusters of this work. Genetic scores $(n=899$ risk scores of individuals in TUEF/TULIP for each of the 5 specific pathways) were transformed to Z-scores to eliminate differences in absolute levels due to the differing number of genetic variants in each genetic pathway. Boxes (hinges) denote the $25^{\text {th }}$ and $75^{\text {th }}$ percentiles with an additional horizontal line indicating the median. Whiskers show the highest and lowest data points excluding outliers (defined as at least 1.5 $\times$ interquartile range below the lower or above the upper hinge). Outliers are shown as individual data points. Differences were tested with one-way ANOVA.

b, Distribution of renal sinus fat (ratio of sinus fat to kidney area, mean of left and right) for $\mathrm{n}=520$ individuals with MRI-assessed renal sinus fat in TUEF/TULIP) across clusters ( $p=1.25 \times 10^{-26}$ with one-way ANOVA). Pairwise tests for cluster 6 with Tukey's test yielded the following $\mathrm{p}$-values: $\mathrm{p}_{5-6}=0.02, \mathrm{p}_{3-6}=0.049, \mathrm{p}_{6 \text {-others }}<1 \times 10^{-14}$. 
medRxiv preprint doi: https://doi.org/10.1101/2020.10.12.20210062; this version posted October 14, 2020. The copyright holder for this preprint (which was not certified by peer review) is the author/funder, who has granted medRxiv a license to display the preprint in It is made available under a CC-BY-NC-ND 4.0 International license

\section{Figure 3. Cluster-specific outcomes}

Kaplan-Meier curves showing cluster-specific probability of not developing diabetes (a, c), nephropathy (c, d) in the TUEF/TULIP and Whitehall-II cohorts, respectively. Cumulative probability of coronary heart disease (CHD, e) and overall mortality (f) are shown for the Whitehall II cohort. For diabetes incidence: $n=421$, mean follow-up 4.1 years, number of diabetes events $=40$ in TUEF/TULIP and $n=6643$, mean followup 16.3 years, number of diabetes events $=828$ in Whitehall II. For microalbuminuria incidence: $n=388$, mean follow-up 4.3 years, number of microalbuminuria events $=71$ in TUEF/TULIP. In Whitehall II n=5182 mean follow-up 18.2 years with 1387 Stage 3 chronic kidney disease or worse (estimated glomerular filtration rate $<60$ $\mathrm{ml} / \mathrm{min} / 1.73 \mathrm{~m}^{2}$ ) incidences. For CHD, $\mathrm{n}=6537$, mean follow-up 17.2 years, 800 events. For all-cause-mortality, $n=6803$, mean follow-up 21.1 years, 825 deaths. All pvalues were computed with two-sided log-rank tests. 
medRxiv preprint doi: https://doi.org/10.1101/2020.10.12.20210062; this version posted October 14, 2020. The copyright holder for this preprint (which was not certified by peer review) is the author/funder, who has granted medRxiv a license to display the preprint in It is made available under a CC-BY-NC-ND 4.0 International license

\section{Tables}


Table 1

Cluster characteristics of the TUEF/TULIP cohort after stratification for the 6 clusters. P-values were computed with one-way ANOVA for continuous variables and two-sided chi-squared tests for categorical variables.

\begin{tabular}{|c|c|c|c|c|c|c|c|}
\hline & 1 & 2 & 3 & 4 & 5 & 6 & p-value \\
\hline & Low risk & $\begin{array}{l}\text { Very low } \\
\text { risk }\end{array}$ & $\begin{array}{l}\text { Beta-cell } \\
\text { failure }\end{array}$ & $\begin{array}{l}\text { Low risk } \\
\text { obese }\end{array}$ & $\begin{array}{l}\text { High risk } \\
\text { insulin } \\
\text { resistant } \\
\text { fatty liver }\end{array}$ & $\begin{array}{l}\text { High risk } \\
\text { visceral fat } \\
\text { nephropathy }\end{array}$ & \\
\hline n & 173 & 154 & 146 & 153 & 91 & 182 & \\
\hline sex $=$ male $(\%)$ & $64(37.0)$ & $59(38.3)$ & $65(44.5)$ & $56(36.6)$ & $35(38.5)$ & $67(36.8)$ & 0.72 \\
\hline age (mean (SD)) & $\begin{array}{l}39.05 \\
(12.55)\end{array}$ & $\begin{array}{l}41.75 \\
(13.29)\end{array}$ & $\begin{array}{l}52.26 \\
(12.11)\end{array}$ & $\begin{array}{l}40.14 \\
(11.85)\end{array}$ & $\begin{array}{l}49.74 \\
(11.81)\end{array}$ & $47.38(12.64)$ & $8.7 \times 10^{-27}$ \\
\hline BMI $\left(\mathrm{kg} / \mathrm{m}^{2}\right)($ mean (SD)) & $\begin{array}{l}26.82 \\
(3.16)\end{array}$ & $\begin{array}{l}23.45 \\
(3.32)\end{array}$ & $\begin{array}{l}29.15 \\
(4.01)\end{array}$ & $\begin{array}{l}31.54 \\
(3.67)\end{array}$ & $\begin{array}{l}34.45 \\
(5.11)\end{array}$ & $34.94(4.90)$ & $1.6 \times 10^{-135}$ \\
\hline $\begin{array}{l}\text { waist circumference }(\mathrm{cm}) \text { (mean } \\
(\mathrm{SD}))\end{array}$ & $\begin{array}{l}88.44 \\
(9.63)\end{array}$ & $\begin{array}{l}80.58 \\
(9.80)\end{array}$ & $\begin{array}{l}97.11 \\
(11.21)\end{array}$ & $\begin{array}{l}99.14 \\
(10.59)\end{array}$ & $\begin{array}{l}108.17 \\
(12.88)\end{array}$ & $107.86(12.34)$ & $1 \times 10^{-111}$ \\
\hline $\begin{array}{l}\text { hip circumference (cm) (mean } \\
\text { (SD)) }\end{array}$ & $\begin{array}{l}101.62 \\
(7.71)\end{array}$ & $\begin{array}{l}95.66 \\
(8.01)\end{array}$ & $\begin{array}{l}105.80 \\
(13.25)\end{array}$ & $\begin{array}{l}112.61 \\
(9.01)\end{array}$ & $\begin{array}{l}115.17 \\
(11.02)\end{array}$ & $117.06(10.58)$ & $3.1 \times 10^{-89}$ \\
\hline $\begin{array}{l}\text { total adipose tissue MRI (liter) } \\
\text { (mean (SD)) }\end{array}$ & $\begin{array}{l}27.71 \\
(6.42)\end{array}$ & $\begin{array}{l}20.75 \\
(7.63)\end{array}$ & $\begin{array}{l}33.27 \\
(9.98)\end{array}$ & $\begin{array}{l}42.34 \\
(9.31)\end{array}$ & $\begin{array}{l}46.20 \\
(12.07)\end{array}$ & $48.28(12.00)$ & $4.4 \times 10^{-142}$ \\
\hline $\begin{array}{l}\text { sq adipose tissue MRI (liter) } \\
\text { (mean (SD)) }\end{array}$ & $8.78(3.13)$ & $5.96(3.50)$ & $\begin{array}{l}10.95 \\
(4.33)\end{array}$ & $\begin{array}{l}15.02 \\
(4.79)\end{array}$ & $\begin{array}{l}16.72 \\
(5.75)\end{array}$ & $18.13(6.19)$ & $1.6 \times 10^{-111}$ \\
\hline $\begin{array}{l}\text { visceral adipose tissue MRI (liter) } \\
\text { (mean (SD)) }\end{array}$ & $2.40(1.48)$ & $1.77(1.21)$ & $\begin{array}{l}4.16 \\
(1.92)\end{array}$ & $3.75(1.97)$ & $\begin{array}{l}5.73 \\
(2.34)\end{array}$ & $5.64(2.44)$ & $1.9 \times 10^{-87}$ \\
\hline $\begin{array}{l}\text { sq to visceral adipose ratio (mean } \\
\text { (SD)) }\end{array}$ & $5.16(3.13)$ & $4.63(2.84)$ & $\begin{array}{l}3.38 \\
(2.18)\end{array}$ & $5.38(3.18)$ & $\begin{array}{l}3.33 \\
(1.56)\end{array}$ & $3.78(1.95)$ & $5 \times 10^{-15}$ \\
\hline $\begin{array}{l}\text { visceral adipose \% of total (mean } \\
\text { (SD)) }\end{array}$ & $0.09(0.06)$ & $0.09(0.06)$ & $\begin{array}{l}0.13 \\
(0.06)\end{array}$ & $0.09(0.06)$ & $\begin{array}{l}0.13 \\
(0.05)\end{array}$ & $0.12(0.06)$ & $5.9 \times 10^{-17}$ \\
\hline liver fat content (mean (SD)) & $3.34(3.25)$ & $2.16(2.90)$ & $\begin{array}{l}5.10 \\
(3.72)\end{array}$ & $3.61(3.51)$ & $\begin{array}{l}20.79 \\
(5.73)\end{array}$ & $9.88(5.49)$ & $5.2 \times 10^{-193}$ \\
\hline fatty-liver disease $(\%)=$ yes $(\%)$ & $28(16.2)$ & $8(5.2)$ & $51(34.9)$ & $26(17.0)$ & $\begin{array}{l}91 \\
(100.0)\end{array}$ & $137(75.3)$ & $3.1 \times 10^{-82}$ \\
\hline
\end{tabular}




\begin{tabular}{|c|c|c|c|c|c|c|c|}
\hline $\begin{array}{l}\text { renal sinus fat (mean of r\&l, \%) } \\
\text { (mean (SD)) }\end{array}$ & $5.20(3.80)$ & $5.77(4.23)$ & $\begin{array}{l}9.42 \\
(4.75)\end{array}$ & $7.15(4.52)$ & $\begin{array}{l}10.02 \\
(4.87)\end{array}$ & $12.07(6.08)$ & $1.3 \times 10^{-26}$ \\
\hline $\begin{array}{l}\text { systolic blood pressure (mmHg) } \\
(\text { mean (SD)) }\end{array}$ & $\begin{array}{l}126.26 \\
(14.15)\end{array}$ & $\begin{array}{l}123.36 \\
(15.81)\end{array}$ & $\begin{array}{l}135.73 \\
(18.59)\end{array}$ & $\begin{array}{l}126.32 \\
(15.43)\end{array}$ & $\begin{array}{l}143.66 \\
(19.34)\end{array}$ & $137.86(17.06)$ & $6.3 \times 10^{-29}$ \\
\hline $\begin{array}{l}\text { diastolic blood pressure (mmHg) } \\
\text { (mean (SD)) }\end{array}$ & $\begin{array}{l}80.25 \\
(10.64)\end{array}$ & $\begin{array}{l}78.52 \\
(11.09)\end{array}$ & $\begin{array}{l}84.93 \\
(12.07)\end{array}$ & $\begin{array}{l}81.16 \\
(10.14)\end{array}$ & $\begin{array}{l}92.57 \\
(13.62)\end{array}$ & $87.47(12.07)$ & $2.5 \times 10^{-24}$ \\
\hline heart rate (mean (SD)) & $\begin{array}{l}69.35 \\
(10.00)\end{array}$ & $\begin{array}{l}67.47 \\
(10.85)\end{array}$ & $\begin{array}{l}69.29 \\
(9.91)\end{array}$ & $\begin{array}{l}68.13 \\
(10.76)\end{array}$ & $\begin{array}{l}75.39 \\
(12.26)\end{array}$ & $72.26(9.64)$ & $1.9 \times 10^{-08}$ \\
\hline $\begin{array}{l}\text { fasting glucose }(\mathrm{mmol} / \mathrm{l})(\text { mean } \\
\text { (SD)) }\end{array}$ & $5.12(0.44)$ & $5.04(0.50)$ & $\begin{array}{l}5.64 \\
(0.55)\end{array}$ & $5.14(0.41)$ & $\begin{array}{l}5.93 \\
(0.58)\end{array}$ & $5.48(0.50)$ & $1.6 \times 10^{-56}$ \\
\hline $\begin{array}{l}\text { post-challenge glucose (mmol/l) } \\
(\text { mean (SD)) }\end{array}$ & $6.12(1.09)$ & $5.99(1.26)$ & $\begin{array}{l}7.87 \\
(1.38)\end{array}$ & $5.72(0.86)$ & $\begin{array}{l}8.31 \\
(1.54)\end{array}$ & $7.10(1.38)$ & $1.2 \times 10^{-80}$ \\
\hline glycaemic category (\%) & & & & & & & $2.3 \times 10^{-68}$ \\
\hline NGT & $139(80.3)$ & $126(81.8)$ & $36(24.7)$ & $131(85.6)$ & $12(13.2)$ & $85(46.7)$ & \\
\hline IFG & $24(13.9)$ & $17(11.0)$ & $41(28.1)$ & $20(13.1)$ & $20(22.0)$ & $46(25.3)$ & \\
\hline IGT & $8(4.6)$ & $10(6.5)$ & $36(24.7)$ & $1(0.7)$ & $14(15.4)$ & $29(15.9)$ & \\
\hline IFG+IGT & $2(1.2)$ & $1(0.6)$ & $33(22.6)$ & $1(0.7)$ & $45(49.5)$ & $22(12.1)$ & \\
\hline GAD antibody = TRUE (\%) & $5(3.2)$ & $4(2.8)$ & $3(2.5)$ & $5(3.7)$ & $2(2.6)$ & $9(5.7)$ & 0.7 \\
\hline $\begin{array}{l}\text { glycated haemoglobin (mmol/mol) } \\
(\text { mean (SD)) }\end{array}$ & $\begin{array}{l}35.67 \\
(4.47)\end{array}$ & $\begin{array}{l}36.77 \\
(4.03)\end{array}$ & $\begin{array}{l}38.95 \\
(6.37)\end{array}$ & $\begin{array}{l}35.80 \\
(3.95)\end{array}$ & $\begin{array}{l}40.06 \\
(3.60)\end{array}$ & $38.23(3.86)$ & $3.1 \times 10^{-19}$ \\
\hline triglycerides (mmol/l) (mean (SD)) & $1.26(0.57)$ & $0.87(0.35)$ & $\begin{array}{l}1.59 \\
(1.17)\end{array}$ & $1.16(0.63)$ & $\begin{array}{l}2.04 \\
(1.13)\end{array}$ & $1.57(0.79)$ & $2.3 \times 10^{-30}$ \\
\hline $\begin{array}{l}\text { insulin sensitivity (Matsuda) } \\
\text { (mean (SD)) }\end{array}$ & $\begin{array}{l}14.54 \\
(6.07)\end{array}$ & $\begin{array}{l}24.33 \\
(9.08)\end{array}$ & $\begin{array}{l}11.52 \\
(5.39)\end{array}$ & $\begin{array}{l}17.63 \\
(7.16)\end{array}$ & $\begin{array}{l}5.99 \\
(3.01)\end{array}$ & $7.46(3.78)$ & $5.3 \times 10^{-128}$ \\
\hline $\begin{array}{l}\text { fasting insulin (pmol//) (mean } \\
\text { (SD)) }\end{array}$ & $\begin{array}{l}51.97 \\
(22.02)\end{array}$ & $\begin{array}{l}32.34 \\
(14.35)\end{array}$ & $\begin{array}{l}54.89 \\
(25.73)\end{array}$ & $\begin{array}{l}48.55 \\
(22.18)\end{array}$ & $\begin{array}{l}113.98 \\
(64.09)\end{array}$ & $99.81(48.55)$ & $5.5 \times 10^{-93}$ \\
\hline insulinogenic index (mean (SD)) & $\begin{array}{l}184.24 \\
(274.80)\end{array}$ & $\begin{array}{l}100.61 \\
(139.56)\end{array}$ & $\begin{array}{l}69.84 \\
(37.14)\end{array}$ & $\begin{array}{l}153.66 \\
(136.01)\end{array}$ & $\begin{array}{l}125.06 \\
(69.77)\end{array}$ & $\begin{array}{l}191.29 \\
(136.68)\end{array}$ & $1.9 \times 10^{-13}$ \\
\hline disposition index (mean (SD)) & $\begin{array}{l}2804.28 \\
(6133.07)\end{array}$ & $\begin{array}{l}2485.30 \\
(5193.75)\end{array}$ & $\begin{array}{l}701.59 \\
(293.53)\end{array}$ & $\begin{array}{l}2475.65 \\
(2227.36)\end{array}$ & $\begin{array}{l}653.97 \\
(357.25)\end{array}$ & $\begin{array}{l}1270.95 \\
(979.49)\end{array}$ & $1.5 \times 10^{-09}$ \\
\hline $\begin{array}{l}\text { C-reactive protein (mg/dl) (mean } \\
\text { (SD)) }\end{array}$ & $0.20(0.34)$ & $0.12(0.25)$ & $\begin{array}{l}0.21 \\
(0.34)\end{array}$ & $0.29(0.32)$ & $\begin{array}{l}0.49 \\
(0.47)\end{array}$ & $0.39(0.42)$ & $2 \times 10^{-18}$ \\
\hline cholesterol (mmol/l) (mean (SD)) & $4.91(0.95)$ & $4.88(0.87)$ & $\begin{array}{l}5.27 \\
(1.02)\end{array}$ & $4.82(0.98)$ & $\begin{array}{l}5.34 \\
(0.93)\end{array}$ & $5.14(0.93)$ & $2.2 \times 10^{-06}$ \\
\hline LDL (mmol/l) (mean (SD)) & $3.04(0.89)$ & $2.73(0.78)$ & $\begin{array}{l}3.22 \\
(0.85)\end{array}$ & $2.97(0.82)$ & $\begin{array}{l}3.41 \\
(0.84)\end{array}$ & $3.15(0.80)$ & $2.1 \times 10^{-09}$ \\
\hline
\end{tabular}




\begin{tabular}{|c|c|c|c|c|c|c|c|}
\hline HDL (mmol/l) (mean (SD)) & $1.34(0.28)$ & $1.69(0.36)$ & $\begin{array}{l}1.32 \\
(0.29)\end{array}$ & $1.27(0.29)$ & $\begin{array}{l}1.18 \\
(0.27)\end{array}$ & $1.28(0.30)$ & $2.8 \times 10^{-45}$ \\
\hline $\begin{array}{l}\text { aspartate-aminotransferase (U/l) } \\
(\text { mean (SD)) }\end{array}$ & $\begin{array}{l}22.38 \\
(6.98)\end{array}$ & $\begin{array}{l}22.79 \\
(7.91)\end{array}$ & $\begin{array}{l}22.52 \\
(7.03)\end{array}$ & $\begin{array}{l}22.14 \\
(6.97)\end{array}$ & $\begin{array}{l}32.73 \\
(14.50)\end{array}$ & $25.18(9.94)$ & $3.8 \times 10^{-21}$ \\
\hline $\begin{array}{l}\text { alanine-aminotransferase (U/l) } \\
(\text { mean (SD)) }\end{array}$ & $\begin{array}{l}24.95 \\
(13.39)\end{array}$ & $\begin{array}{l}22.41 \\
(10.12)\end{array}$ & $\begin{array}{l}25.42 \\
(10.48)\end{array}$ & $\begin{array}{l}26.34 \\
(15.06)\end{array}$ & $\begin{array}{l}48.47 \\
(34.70)\end{array}$ & $34.24(18.43)$ & $3 \times 10^{-32}$ \\
\hline $\begin{array}{l}\text { gamma-glutamyl transferase (U/l) } \\
\text { (mean (SD)) }\end{array}$ & $\begin{array}{l}22.82 \\
(19.52)\end{array}$ & $\begin{array}{l}18.24 \\
(15.11)\end{array}$ & $\begin{array}{l}28.49 \\
(26.08)\end{array}$ & $\begin{array}{l}21.48 \\
(14.03)\end{array}$ & $\begin{array}{l}39.82 \\
(34.49)\end{array}$ & $33.90(26.46)$ & $8 \times 10^{-16}$ \\
\hline $\begin{array}{l}\text { serum creatinine }(\mathrm{mg} / \mathrm{dl})(\text { mean } \\
\text { (SD)) }\end{array}$ & $0.83(0.18)$ & $0.81(0.17)$ & $\begin{array}{l}0.82 \\
(0.18)\end{array}$ & $0.82(0.15)$ & $\begin{array}{l}0.78 \\
(0.15)\end{array}$ & $0.79(0.17)$ & 0.18 \\
\hline $\begin{array}{l}\text { urinary albumin-creatinine ratio } \\
\text { (mean (SD)) }\end{array}$ & $\begin{array}{l}17.31 \\
(35.16)\end{array}$ & $\begin{array}{l}18.46 \\
(28.62)\end{array}$ & $\begin{array}{l}16.05 \\
(14.97)\end{array}$ & $\begin{array}{l}17.58 \\
(30.75)\end{array}$ & $\begin{array}{l}24.11 \\
(45.77)\end{array}$ & $16.51(16.75)$ & 0.53 \\
\hline $\begin{array}{l}\text { carotid intima media thickness } \\
(\mathrm{mm})(\text { mean }(\mathrm{SD}))\end{array}$ & $0.52(0.12)$ & $0.53(0.10)$ & $\begin{array}{l}0.63 \\
(0.13)\end{array}$ & $0.54(0.12)$ & $\begin{array}{l}0.64 \\
(0.12)\end{array}$ & $0.60(0.12)$ & $2.8 \times 10^{-13}$ \\
\hline polygenic risk score (mean (SD)) & $\begin{array}{l}-0.09 \\
(0.97)\end{array}$ & $0.15(0.91)$ & $\begin{array}{l}0.24 \\
(0.92)\end{array}$ & $\begin{array}{l}-0.17 \\
(0.91)\end{array}$ & $\begin{array}{l}0.11 \\
(0.81)\end{array}$ & $-0.07(1.01)$ & 0.00057 \\
\hline family history of diabetes (\%) & & & & & & & 0.0084 \\
\hline a_no family history & $64(38.1)$ & $58(39.5)$ & $42(29.6)$ & $64(42.7)$ & $27(31.0)$ & $72(41.1)$ & \\
\hline b_second degree relative & $37(22.0)$ & $35(23.8)$ & $22(15.5)$ & $38(25.3)$ & $15(17.2)$ & $29(16.6)$ & \\
\hline c_first degree relative & $67(39.9)$ & $54(36.7)$ & $78(54.9)$ & $48(32.0)$ & $45(51.7)$ & $74(42.3)$ & \\
\hline ever smoked = yes $(\%)$ & $86(49.7)$ & $65(42.2)$ & $82(56.2)$ & $81(52.9)$ & $45(49.5)$ & $113(62.1)$ & 0.011 \\
\hline current smoking $=$ yes $(\%)$ & $16(9.9)$ & $8(5.7)$ & $15(11.0)$ & $12(8.5)$ & $2(2.4)$ & $18(10.7)$ & 0.16 \\
\hline $\begin{array}{l}\text { cholesterol lowering medication = } \\
\text { yes }(\%)\end{array}$ & $6(3.5)$ & $0(0.0)$ & $8(5.5)$ & $2(1.3)$ & $1(1.1)$ & $6(3.3)$ & 0.038 \\
\hline antihypertensive medication $=$ yes & $10(5.8)$ & $3(1.9)$ & $21(14.4)$ & $2(1.3)$ & $25(27.5)$ & $44(24.2)$ & $3.6 \times 10^{-17}$ \\
\hline
\end{tabular}


medRxiv preprint doi: https://doi.org/10.1101/2020.10.12.20210062; this version posted October 14,2020 . The copyright holder for this preprint (which was not certified by peer review) is the author/funder, who has granted medRxiv a license to display the preprint in It is made available under a CC-BY-NC-ND 4.0 International license .

\section{Methods}

\section{TUEF/TULIP cohort}

Prediabetes subphenotyping was initially performed on a complete cases subset of participants of the Tuebingen Family study and Tuebingen Lifestyle Program (TUEF/TULIP) $)^{2,3}$, who had no missing values for the preselected phenotyping variables $(\mathrm{N}=899$, baseline characteristics for this and the whole cohort are shown in the Suppl.Table 11). Participants were recruited from 2003 through 2018. Recruitment was mostly performed via newspaper announcements and e-mail bulletins. The studies have been designed to phenotype individuals at increased risk of diabetes. Eligibility criteria for inclusion comprised either a history of prediabetes, a family history of diabetes, a BMI greater than $27 \mathrm{~kg} / \mathrm{m}^{2}$ or a history of gestational diabetes ${ }^{2}$. Participants underwent a frequently sampled OGTT and received MR-tomography-based measurement of body fat distribution and ${ }^{1} \mathrm{H}-\mathrm{MR}$-spectroscopy-based measurements of hepatic fat content. Follow-up data was available for individuals who responded to invitations to follow-up appointments or participated in follow-up studies. The followup measurements were comparable to the initial assessments. Glycemic traits (fasting glucose, OGTT or HbA1c) were available for 421 participants, whereas urine sample during follow-up, for the determination of microalbuminuria, was available for 388 participants. The study protocol was approved by the Ethics Committee of the University of Tübingen (422/2002). All participants gave written informed consent.

\section{Whitehall II cohort}

Data from the occupational Whitehall II cohort were accessed by a data sharing agreement. Details of the study have been described elsewhere ${ }^{4}$. In brief, the study was established to explore the relationship between socio-economic status, stress and cardiovascular disease. All London-based civil servants aged 33-55 years were invited in 1985-1988 and $10.308(73 \%)$ participated. Since then, 5 further clinical examinations have taken place that are available for data sharing at approximately 5year intervals (phases 3,5, 7, 9 and 11). The study was approved by the Joint UCL/UCLH Committees on the Ethics of Human Research (Committee Alpha). For the current analysis, the baseline was defined as the first available fasting OGTT $(>=8$ 
medRxiv preprint doi: https://doi.org/10.1101/2020.10.12.20210062; this version posted October 14,2020 . The copyright holder for this preprint (which was not certified by peer review) is the author/funder, who has granted medRxiv a license to display the preprint in It is made available under a CC-BY-NC-ND 4.0 International license .

hours of fasting for morning and $>=5$ hours of fasting after a light fat-free breakfast eaten before 8 am for afternoon OGTTs). Participants with prevalent or incident diabetes at baseline and those with non-white ethnicities were excluded. From the 6916 available baseline OGTTs, 6810 were complete cases in regards of the used clustering variables und underwent cluster assignments. The cohort characteristics are reported in Suppl.Table 12.

\section{Variable selection and de novo clustering in TUEF/TULIP}

We aimed to identify subphenotypes that reflect differences in pathophysiological processes in the natural history of type 2 diabetes. The main paradigm of type 2 diabetes pathogenesis is an insufficient compensatory increase of insulin secretion in response to insulin resistance ${ }^{31}$. Therefore, insulin sensitivity and insulin secretion are key variables ${ }^{6,7}$. We used OGTT-based indices of insulin sensitivity (Matsuda-index) ${ }^{32}$ and insulin secretion ( $\mathrm{AUC}_{0-30} \mathrm{C}$-peptide/ $\mathrm{AUC}_{0-30}$ glucose) that correlate well with gold-standard measures and are preferable to static measurements obtained in the fasting state ${ }^{33,34}$. Glycaemia was quantified in the partitioning procedure as $\mathrm{AUC}_{0-120}$ glucose. Furthermore, we aimed to capture diverse etiologies of insulin resistance by accounting for visceral and subcutaneous adipose tissue volume (VAT and SCAT), that have distinct metabolic characteristics ${ }^{35}$. We especially focused on elevated liver fat content, as it is strongly associated with insulin resistance ${ }^{36}$. HDL-cholesterol levels have been long known as explanatory variables of the metabolic syndrome and insulin resistance ${ }^{37}$. Moreover, causal inference from large genomic datasets provides evidence not only for a genetic correlation of HDL-cholesterol levels with type 2 diabetes, but also for a causal link between HDL-cholesterol levels and type 2 diabetes $^{9}$. We also added a genome-wide polygenic risk score (PRS) to the analysis to better differentiate between genetically determined beta-cell dysfunction and environmentally determined beta-cell dysfunction. The correlation of the clustering variables is reported in Suppl.Table 13.

For computation of the PRS, we used the LDpred algorithm of Vilhjalmson et al. ${ }^{38}$ on a combination of BMI-adjusted effect sizes and p-values from a meta-analysis in $\sim 900.000$ European individuals and genotypes ${ }^{11}$. After quality control, exclusion of multi-allelic and low-frequency variants, we combined 484.788 variants from the two 
medRxiv preprint doi: https://doi.org/10.1101/2020.10.12.20210062; this version posted October 14,2020 . The copyright holder for this preprint (which was not certified by peer review) is the author/funder, who has granted medRxiv a license to display the preprint in It is made available under a CC-BY-NC-ND 4.0 International license .

datasets, yielding an estimated genome-wide SNP-heritability of 0.069. Of the top 94 diabetes-related genetic variants shown in the latest large-scale genome-wide association study ${ }^{11}, 63$ were genotyped in TUEF/TULIP. The association of clusterassignment with the genotype was tested separately for each variant using ANOVA to analyze the enrichment of certain genotypes in clusters. A further geneticpathophysiologic classification of clusters was performed according to data from Udler et $\mathrm{al}^{12}$. Here, we computed the genetic risk score for every individual and every genetic class (beta-cell, proinsulin, obesity, lipodystrophy and liver/lipid) taking only weights $>=0.75$ into account, as described in the original publication. The classification of glucose response curves according to Hulman et al (Hulman-classes) was performed with the corresponding web-calculator from 5-point OGTT glucose values in the TUEF/TULIP study ${ }^{13}$.

\section{Cluster assignment in the Whitehall II cohort}

For assigning participants in the Whitehall II cohort to clusters established in TUEF/TULIP, we used proxy variables. Since liver fat, visceral adipose tissue and subcutaneous adipose tissue were not available in the Whitehall II cohort, and only two-point OGTTs were performed, other anthropometric variables and analytes were employed instead of these variables. Variables were selected based on statistical consideration (correlation) and pathophysiologic (theoretical) connection to the original trait (e.g. liver fat - fasting triglycerides, fasting insulin and waist circumference). Transaminase activity was not available during the early phases of the Whitehall II study. The final variable set was selected upon the highest agreement in re-identification of the original cluster assignments using the new proxy variables in TUEF. The variables used in Whitehall II comprised glycemia during glucose challenge, insulin sensitivity ${ }^{32}$, Stumvoll's first phase insulin secretion index using insulin and glucose levels at fasting and at 120 min during OGTT $^{39}$, fasting insulin, fasting triglycerides, waist circumference, hip circumference, BMI and HDLcholesterol. The median values of these variables in TUEF/TULIP were used to assign participants to clusters in Whitehall II (Extended data 1) by taking the nearest neighbors of the 6 cluster-centers based upon Euclidean distances. Since Whitehall-II used a restricted CVD-focused genotyping platform with only 48000 markers and the release of full-scale genotyping data was not readily available, we decided to omit the 
medRxiv preprint doi: https://doi.org/10.1101/2020.10.12.20210062; this version posted October 14,2020 . The copyright holder for this preprint (which was not certified by peer review) is the author/funder, who has granted medRxiv a license to display the preprint in It is made available under a CC-BY-NC-ND 4.0 International license .

genetic risk score from the re-assignment procedure. Despite these limitations, successful re-assignment of the clusters was achieved in $63 \%$ of the original TUEF cohort.

\section{OGTT and laboratory analysis}

All participants of TUEF/TULIP received a 75-g glucose solution (Accu-Check Dextro, Roche) at 8 a.m. following an overnight fast. Venous blood was obtained through an indwelling venous catheter before and 30, 60, 90 and 120 minutes after glucose ingestion. In the Whitehall II cohort, the OGTT procedure has been described earlier. In short, venous blood samples were collected after an overnight fast in the morning ( $\geq 8$ hours of fasting) or in the afternoon after no more than a light fat-free breakfast eaten before $08.00 \mathrm{~h}$ ( $\geq 5$ hours of fasting) followed by a standard $75 \mathrm{~g}$ OGTT with a venous blood sample taken 2 hours after ingestion of the glucose solution. Glucose was analyzed in the Whitehall II study using an YSI glucose analyser (Yellow Springs Instruments). Glucose values were measured in TUEF/TULIP directly using a bedside glucose analyzer (YSI, Yellow Springs, CO or Biosen C-line, EKF-diagnostic, Barleben). In TUEF/TULIP, all other obtained blood samples were put on ice, the serum was centrifuged within 2 hours. Plasma insulin and C-peptide were determined by an immunoassay with the ADVIA Centaur XP Immunoassay System and HDL was measured using the ADVIA XPT clinical chemical analyser (all from Siemens Healthineers, Eschborn, Germany), while triglycerides were measured with standard colorimetric methods using a Bayer analyzer. In Whitehall II, insulin was measured with an in-house human insulin RIA and later with a DAKO ELISA kit (DAKO Cytomatin Ltd, Ely, UK). Serum creatinine was measured using a kinetic colorimetric (Jaffe) method on a Roche "P" Modular system (phase 9) and on a COBAS 8000 system (phase 11). Lipid measurements were described previously ${ }^{40}$. HbA1c measurements were performed using Tosoh glycohemoglobin analyzers in both studies (Tosoh Bioscience Tokyo Japan).

\section{Body fat distribution, liver fat content and renal sinus fat}

Body fat distribution variables, i.e., VAT and SCAT, were determined by whole-body T1-weighted MRI as described earlier ${ }^{41}$. Liver fat content was measured by volume selective ${ }^{1} \mathrm{H}-\mathrm{MR}$ spectroscopy ${ }^{42}$. Renal sinus fat was measured with manual segmentation from MR image slices specifically in cluster 5 and 6 using a method 
medRxiv preprint doi: https://doi.org/10.1101/2020.10.12.20210062; this version posted October 14,2020 . The copyright holder for this preprint (which was not certified by peer review) is the author/funder, who has granted medRxiv a license to display the preprint in It is made available under a CC-BY-NC-ND 4.0 International license .

described previously ${ }^{14}$. The operator performing the segmentation (JM) was not aware of the cluster assignments. The procedure could not be completed in 6 participants ( $2 \%$ missing) due to breathing artefacts in the images. Renal sinus fat data for clusters 1 to 4 were partly available from segmentations for previous projects (mean data availability $40 \%$ over cluster 1 to 4$)$.

\section{Outcomes}

For detection of incident diabetes, either of the following was used: clinically ascertained diabetes (from patient history, or by the use of a diabetes-medication), an elevated fasting glucose $(>=7 \mathrm{mmol} / \mathrm{l})$, post-challenge glucose $(>=11.1 . \mathrm{mmol} / \mathrm{l}$, or $\mathrm{HbA} 1 \mathrm{c}(48 \mathrm{mmol} / \mathrm{mol}$ or $6.5 \%)$ in both cohorts. To assess the Ahlqvist-classification ${ }^{6}$ for the subtypes of diabetes in Whitehall II, we used insulin-based HOMA2-indices, because C-peptide was not measured. GAD measurements were not available. HbA1c assessment had been introduced beginning with Phase 7. Cluster assignment was performed using the lowest Euclidean distances from the published cluster centers in the All New Diabetes in Scania (ANDIS) cohort after scaling the variables for the means and SDs of the ANDIS cohort. Microalbuminuria was assessed in TUEF/TULIP upon the first occurrence from morning spot urine using the albumin-tocreatinine ratio (ACR). Measurements with excessive leukocyturia (175 measurements out of 3218) were excluded from this analysis. Microalbuminuria was established with an $\mathrm{ACR}>=30 \mathrm{mg} / \mathrm{g}$ creatinine. Carotid intima-media thickness (IMT), which is associated with future cardiovascular and cerebrovascular events ${ }^{43}$, was determined by a high-resolution ultrasound of the left and right common carotid artery. A trained physician who was unaware of the clinical and laboratory variables of the participants performed B-mode ultrasound imaging using a linear ultrasound transducer (10-13 MHz; AU5 Harmonic, ESAOTE BIOMEDICA, Hallbergmoos, Germany). IMT was specified according to the European Mannheim carotid intima-media thickness consensus criteria ${ }^{44}$. To ascertain renal disease, we used estimated glomerular filtration rate calculated using the CKD-EPI creatinine equation ${ }^{45}$. Serum creatinine was available from phase 9. Only participants with at least one eGFR value went into these analyses. Stages of chronic kidney disease were ascertained with the Kidney Disease: Improving Global Outcomes (KDIGO) classification ${ }^{46}$. Ascertainment of coronary heart disease and mortality in Whitehall-II has been described earlier ${ }^{47}$. In brief, 
medRxiv preprint doi: https://doi.org/10.1101/2020.10.12.20210062; this version posted October 14,2020 . The copyright holder for this preprint (which was not certified by peer review) is the author/funder, who has granted medRxiv a license to display the preprint in It is made available under a CC-BY-NC-ND 4.0 International license .

incident CHD was defined as CHD death, nonfatal CHD and typical angina ascertained from clinical records, without self-reported cases from the Rose angina questionnaire. The cases were ascertained from participants' general practitioners, information extracted from hospital medical records by study nurses, or data from the NHS Hospital Episode Statistics (HES) and death register databases obtained after linking the participants' unique NHS identification numbers to this national database. Mortality data until June 2015 was drawn from the British National Mortality Register (National Health Service [NHS] Central Register) using each participants’ NHS identification number.

\section{Statistical analysis}

Statistical analyses were performed using R version $3.4 .3^{48}$. In the clustering analysis, distances were computed as Gower-distances using standardized variables (scaled to a mean of 0 and SD of 1). Participants with outlier variables (absolute standardized levels $>=5$ ) were excluded from the clustering procedure. To find the optimal cluster count, we evaluated the dendogram and silhouette-widths. The clustering procedure was performed with the partitioning around medoids (pam) method in the R-package "cluster", which is a more robust version of k-means clustering ${ }^{49}$. Using repeated subsetting with the clusterboot function from the fpc package, the mean Jaccardsimilarity measure was 0.74 across all clusters. ${ }^{50}$ To further validate the stability of clusters, we iterated the clustering procedure for each of the 429 participants who had repeated measurements comprising all clustering variables (mean number of measurements 2.6 \pm 0.9 , follow-up duration $4.2 \pm 3.6$ years, also see Extended Data 8). We assessed the per-participant agreement of the generated 1112 cluster assignments using interrater reliabilities. The ICC2k value for cluster agreement was 0.72 (CI 0.68 - 0.76). Detailed reports on means and SDs of the clustering variables in both cohorts and the cluster medians are provided in Suppl.Tables 14-15.

Cluster means were compared using ANOVA. Specific outcomes were compared using ANCOVA adjusting for covariates such as sex, age and BMI. Post-hoc comparisons were performed using Tukey's honest significant differences procedure. Endpoints related to diabetes complications were analyzed in the follow-up data of both cohorts using survival analysis and proportional hazard models. Differences in cumulative risks for reaching endpoints were tested with log-rank tests. When not 
medRxiv preprint doi: https://doi.org/10.1101/2020.10.12.20210062; this version posted October 14, 2020. The copyright holder for this preprint (which was not certified by peer review) is the author/funder, who has granted medRxiv a license to display the preprint in It is made available under a CC-BY-NC-ND 4.0 International license.

indicated otherwise, the uncorrected p-value of a specific cluster's risk relative to cluster 1 is provided in the proportional hazard analysis. Given the relatively low number of outcomes in TUEF/TULIP (40 for diabetes and 71 for microalbuminuria), assessment of proportional hazards adjusted for potential confounders was performed in the Whitehall II cohort only. Proportional hazards assumptions were tested by visualization of the Schoenfeld-residuals. The performed statistical tests were twosided. 
medRxiv preprint doi: https://doi.org/10.1101/2020.10.12.20210062; this version posted October 14,2020 . The copyright holder for this preprint (which was not certified by peer review) is the author/funder, who has granted medRxiv a license to display the preprint in It is made available under a CC-BY-NC-ND 4.0 International license .

\section{Data availability}

For TUEF/TULIP, all requests for data and materials will be promptly reviewed by the Data Access Steering Committee of the Institute of Diabetes and Metabolic Research, Tübingen to verify if the request is subject to any intellectual property or confidentiality obligations. Individual level data may be subject to confidentiality. Any data and materials that can be shared will be released via a Material Transfer Agreement. Data access to individual-level data of the Whitehall II study is subject to a separate data sharing agreement according to the data sharing policy of Whitehall II. This policy conforms to the MRC Policy on Research Data Sharing. More details can be found on the Whitehall II webpage: https:/www.ucl.ac.uk/epidemiology-healthcare/research/epidemiology-and-public-health/research/whitehall-ii/data-sharing.

\section{Code availability}

The $\mathrm{R}$ code used to generate all results of this manuscript is available upon request. Requests will be reviewed by the Data Access Steering Committee of the Institute of Diabetes and Metabolic Research, Tübingen.

\section{Methods-only References}

31. Weyer, C., Bogardus, C., Mott, D. M. \& Pratley, R. E. The natural history of insulin secretory dysfunction and insulin resistance in the pathogenesis of type 2 diabetes mellitus. Journal of Clinical Investigation 104, 787-794 (1999).

32. Matsuda, M. \& DeFronzo, R. A. Insulin sensitivity indices obtained from oral glucose tolerance testing: comparison with the euglycemic insulin clamp. Diabetes Care 22, 1462-1470 (1999).

33. Herzberg-Schäfer, S. et al. Evaluation of fasting state-/oral glucose tolerance testderived measures of insulin release for the detection of genetically impaired $\beta$-cell function. PloS one 5, (2010).

34. Wagner, R. et al. A novel insulin sensitivity index particularly suitable to measure insulin sensitivity during gestation. Acta Diabetol 53, 1037-1044 (2016). 
medRxiv preprint doi: https://doi.org/10.1101/2020.10.12.20210062; this version posted October 14,2020 . The copyright holder for this preprint (which was not certified by peer review) is the author/funder, who has granted medRxiv a license to display the preprint in It is made available under a CC-BY-NC-ND 4.0 International license .

35. Siegel-Axel, D. I. \& Häring, H. U. Perivascular adipose tissue: An unique fat compartment relevant for the cardiometabolic syndrome. Rev Endocr Metab Disord 1-10 (2016) doi:10.1007/s11154-016-9346-3.

36. Stefan, N., Kantartzis, K. \& Häring, H.-U. Causes and metabolic consequences of Fatty liver. Endocr. Rev 29, 939-960 (2008).

37. Eckel, R. H., Grundy, S. M. \& Zimmet, P. Z. The metabolic syndrome. The Lancet 365, 1415-1428 (2005).

38. Vilhjálmsson, B. J. et al. Modeling Linkage Disequilibrium Increases Accuracy of Polygenic Risk Scores. The American Journal of Human Genetics 97, 576-592 (2015).

39. Stumvoll, M., Van Haeften, T., Fritsche, A. \& Gerich, J. Oral glucose tolerance test indexes for insulin sensitivity and secretion based on various availabilities of sampling times. Diabetes Care 24, 796-797 (2001).

40. Bouillon, K. et al. Decline in low-density lipoprotein cholesterol concentration: lipid-lowering drugs, diet, or physical activity? Evidence from the Whitehall II study. Heart 97, 923-930 (2011).

41. Machann, J. et al. Standardized assessment of whole body adipose tissue topography by MRI. J Magn Reson Imaging 21, 455-462 (2005).

42. Stefan, N. et al. Inhibition of 11ß-HSD1 with RO5093151 for non-alcoholic fatty liver disease: a multicentre, randomised, double-blind, placebo-controlled trial. The Lancet Diabetes \& Endocrinology 2, 406-416 (2014).

43. Bots Michiel L., Hoes Arno W., Koudstaal Peter J., Hofman Albert \& Grobbee Diederick E. Common Carotid Intima-Media Thickness and Risk of Stroke and Myocardial Infarction. Circulation 96, 1432-1437 (1997). 
medRxiv preprint doi: https://doi.org/10.1101/2020.10.12.20210062; this version posted October 14, 2020. The copyright holder for this preprint (which was not certified by peer review) is the author/funder, who has granted medRxiv a license to display the preprint in It is made available under a CC-BY-NC-ND 4.0 International license.

44. Touboul, P.-J. et al. Mannheim Carotid Intima-Media Thickness and Plaque Consensus (2004-2006-2011). CED 34, 290-296 (2012).

45. Levey, A. S. et al. A New Equation to Estimate Glomerular Filtration Rate. Ann Intern Med 150, 604-612 (2009).

46. Levey, A. S. et al. Definition and classification of chronic kidney disease: A position statement from Kidney Disease: Improving Global Outcomes (KDIGO). Kidney International 67, 2089-2100 (2005).

47. Ferrie, J. E., Kivimäki, M., Shipley, M. J., Smith, G. D. \& Virtanen, M. Job insecurity and incident coronary heart disease: the Whitehall II prospective cohort study. Atherosclerosis 227, 178-181 (2013).

48. R Core Team. R: A Language and Environment for Statistical Computing. (R Foundation for Statistical Computing, 2015).

49. Reynolds, A. P., Richards, G., de la Iglesia, B. \& Rayward-Smith, V. J. Clustering Rules: A Comparison of Partitioning and Hierarchical Clustering Algorithms. $J$ Math Model Algor 5, 475-504 (2006).

50. Hennig, C. Cluster-wise assessment of cluster stability. Computational Statistics and Data Analysis 258-271 (2007). 

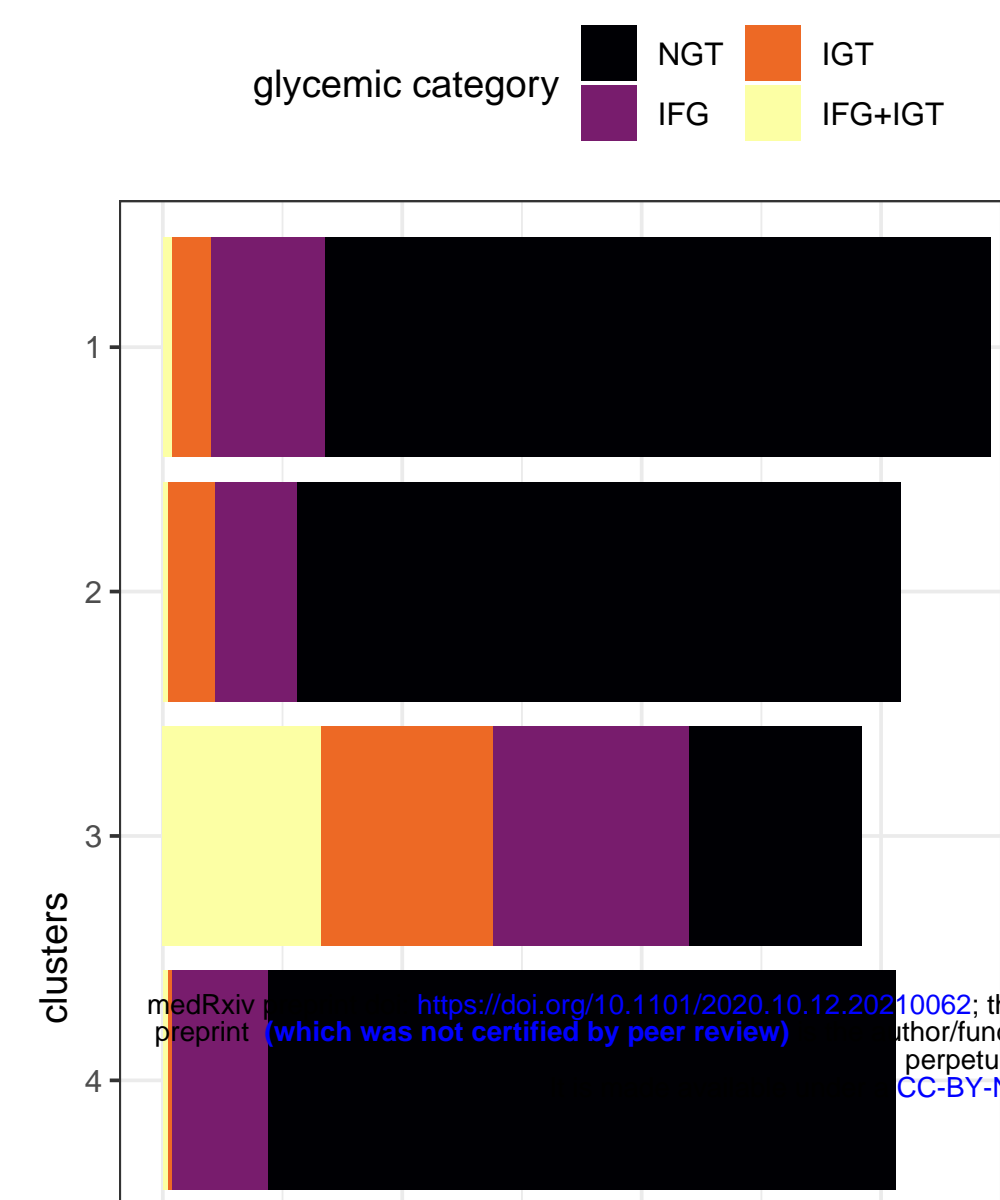

10062; this version posted October 14, 2020luTheefo\$pyright holder for this hor/funder, who has granted medRxiv a license to display the preprint in $\begin{array}{ll}\text { perpetuity. } & \text { SC } \\ \text { CC-BY-NC-ND } 4.0 \text { International licensenetic } & \text { SC } \\ \text { risk } & \text { adi }\end{array}$
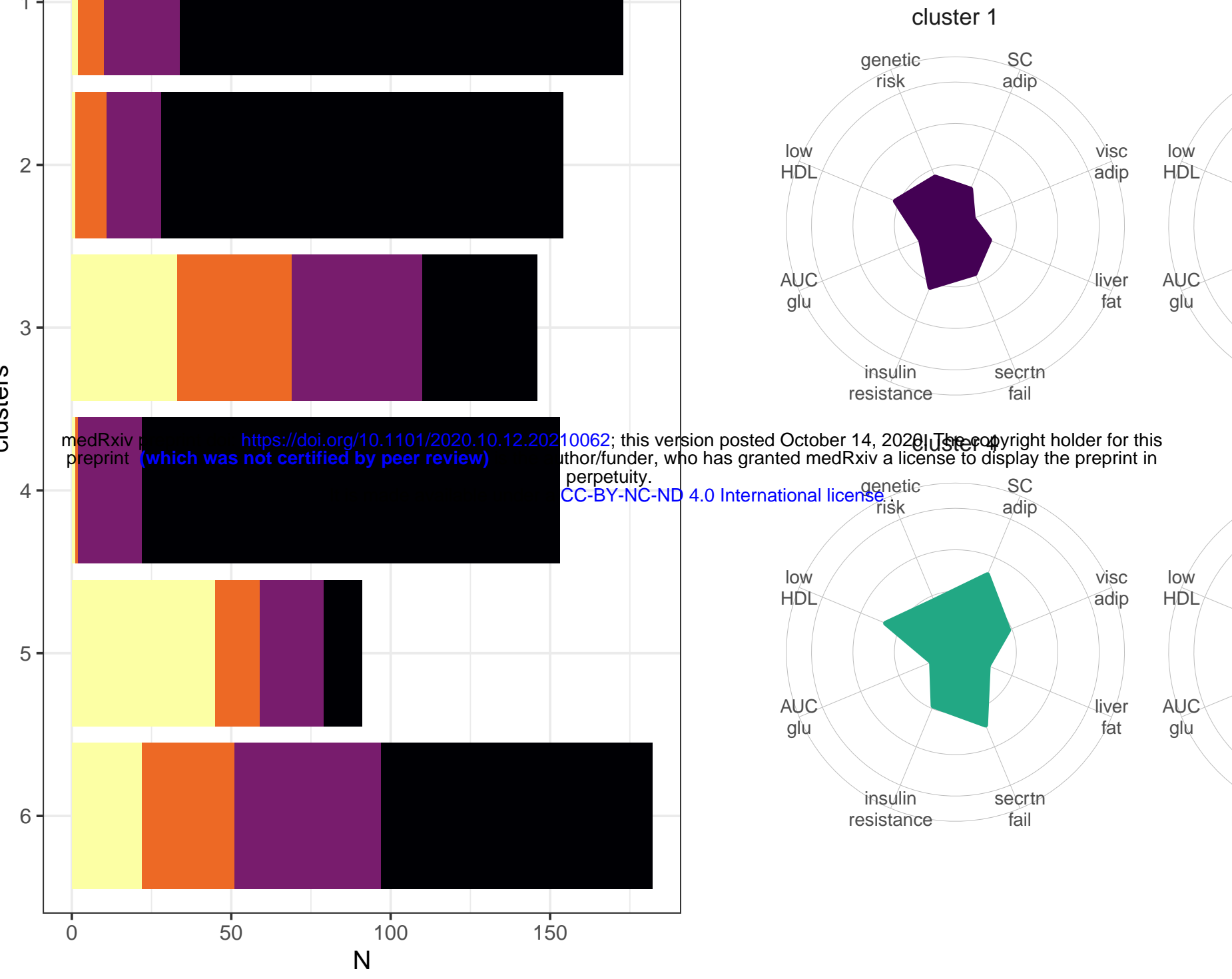

C

glu

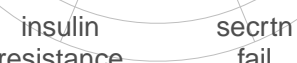

fail

\section{d}

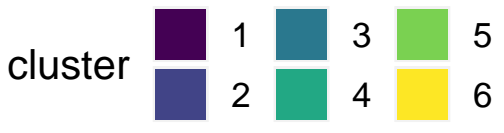
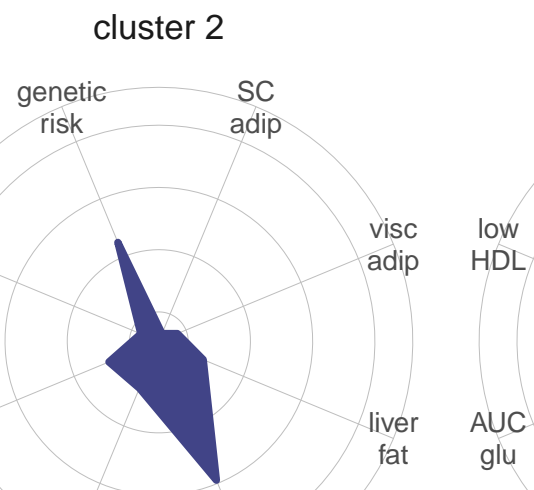

$\begin{array}{lc}\text { insulin } & \text { secrtn } \\ \text { resistance } & \text { fail }\end{array}$

cluster 5

$\begin{array}{cc}\text { genetic } & \text { SC } \\ \text { risk } & \text { adip }\end{array}$

cluster 3

genetic SC

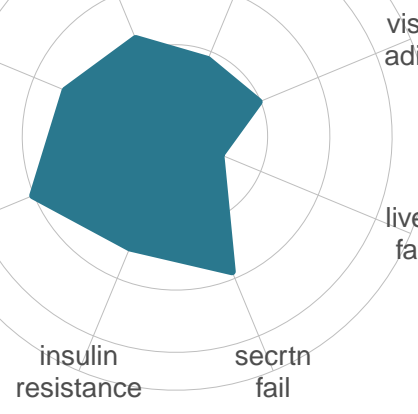

cluster 6

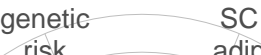

risk adip

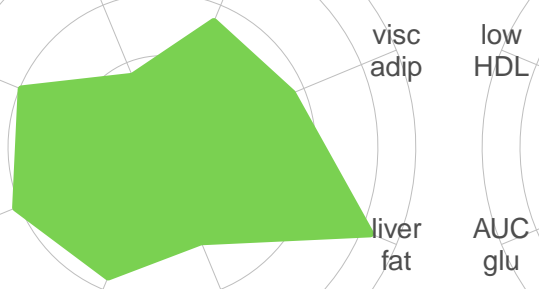

insulin secrtn

insulin secrtn
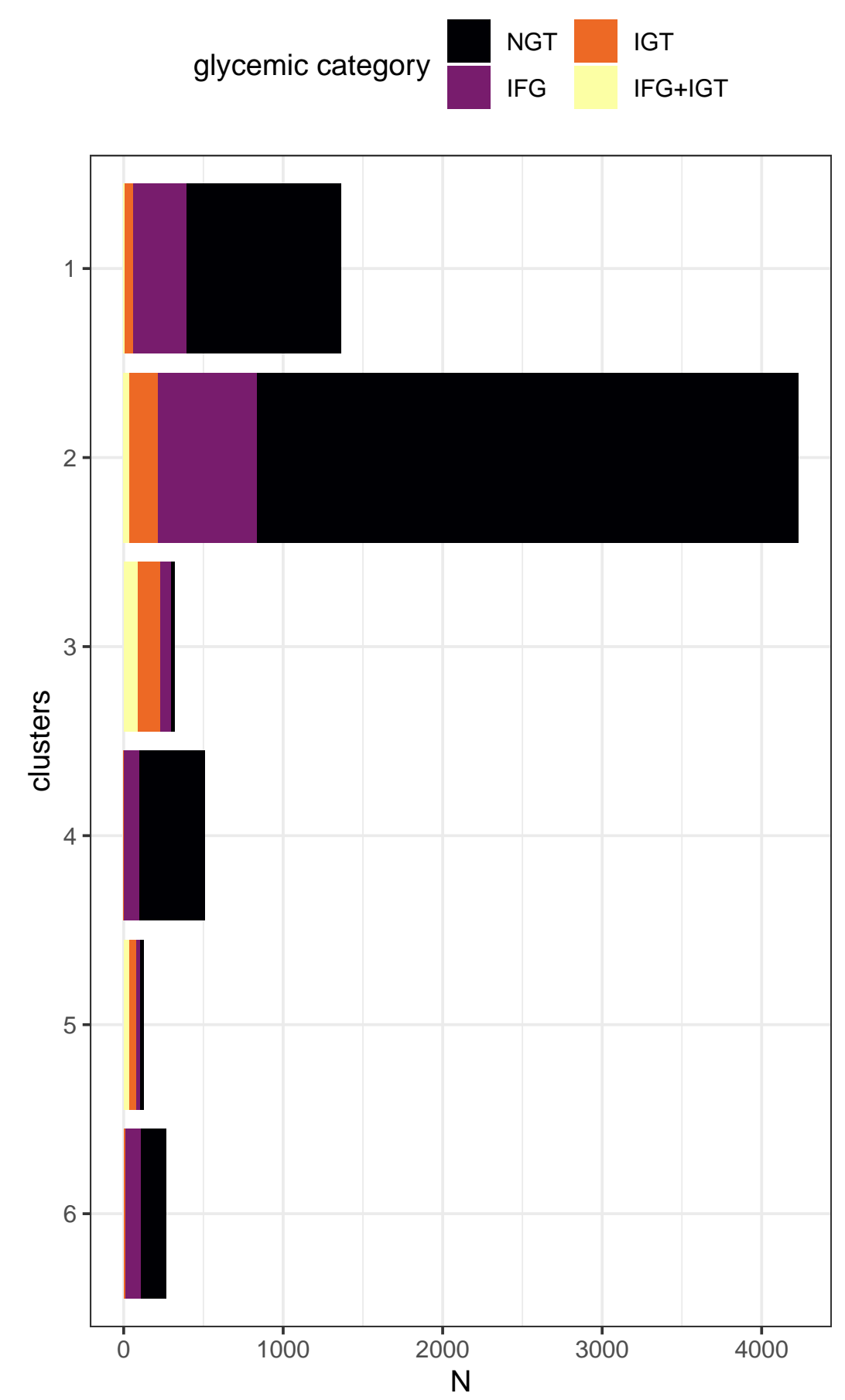

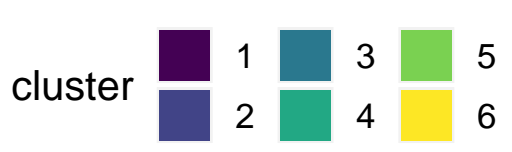

cluster 1

BMI waist

cluster 2

cluster 3

BMI waist

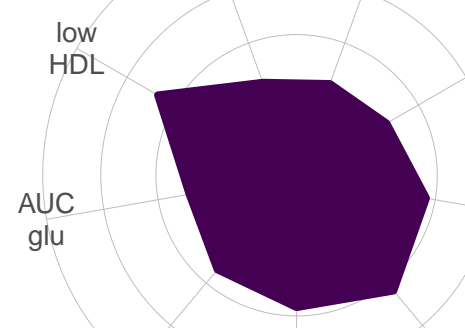

hip low

insulin

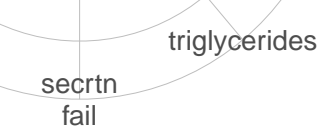

cluster 4

BMI waist

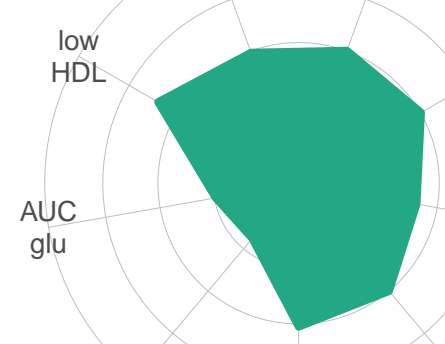

insulin
resistance

triglycerides secrtn
fail fst AUC
ins glu

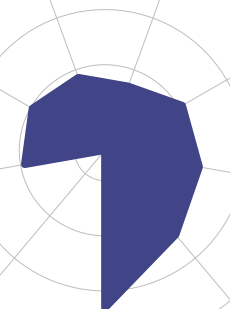

insulin
resistance

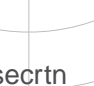

secrth
fail

cluster 5

BMI waist

hip

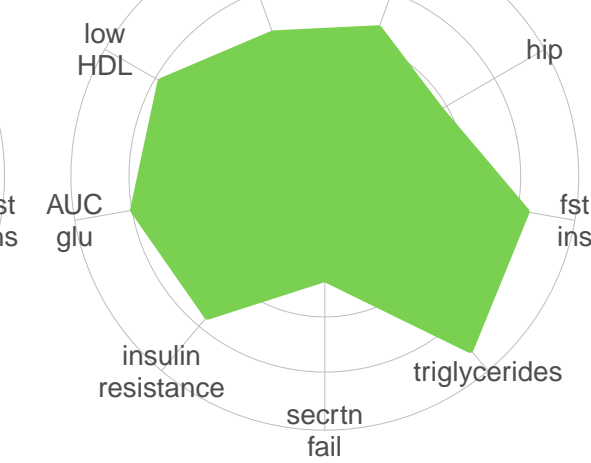

low

fst AUC
ins glu

insulin

insulin
resistance
BMI waist

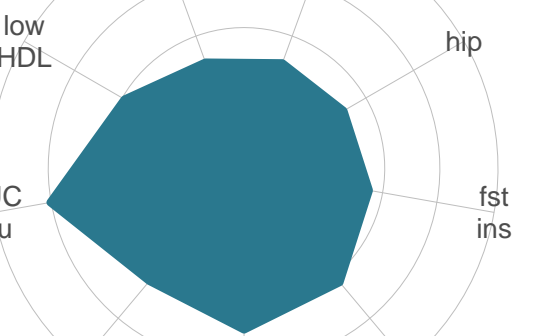

insulín

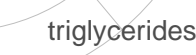

secrtn

cluster 6

BMI waist

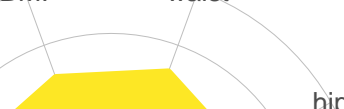

hip

fst
ins 

a. TUEF/TULIP

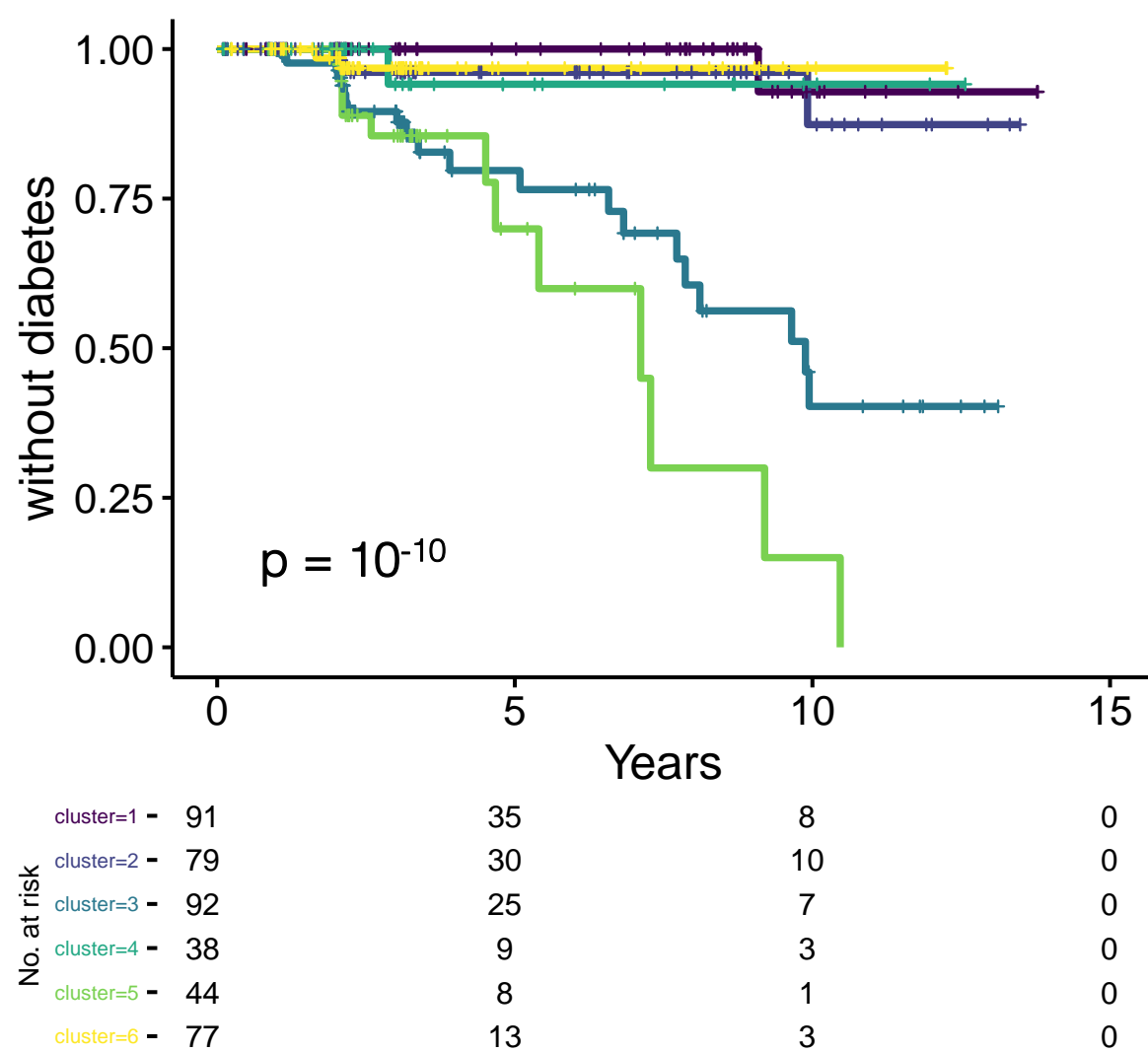

cluster $=1-0$

Do cluster=2 - 0

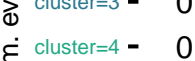

डे cluster=5 - 0

\section{c. Whitehall II}
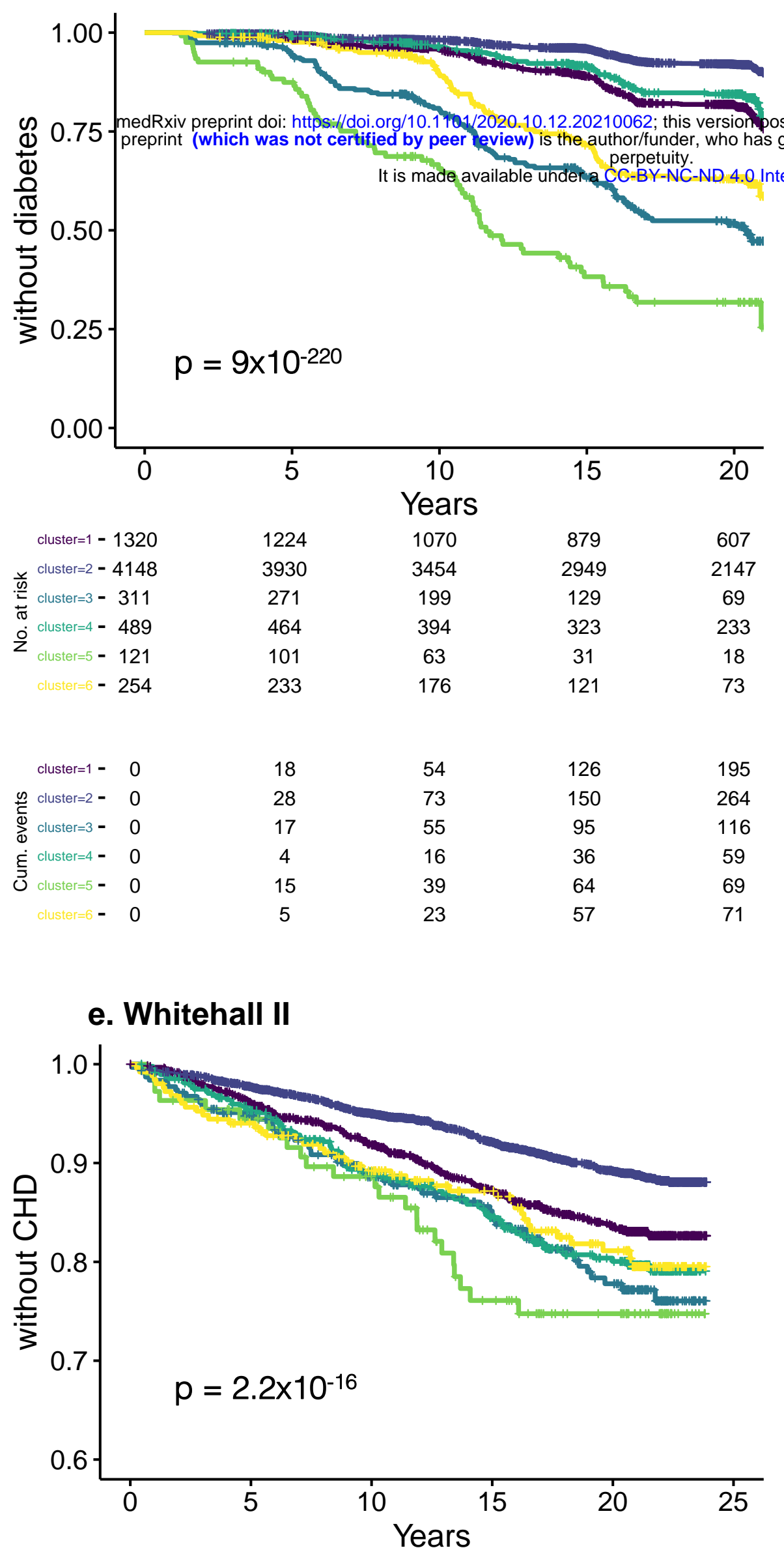

O

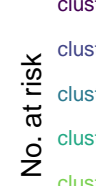

ì cluster $=4$ -

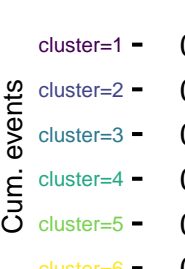

\section{e. Whitehall II}

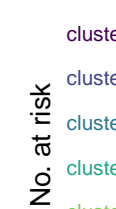

cluster $=3-309$

cluster $=4-478$

$\begin{array}{cccc}1188 & 1047 & 894 & 718 \\ 3890 & 3489 & 3039 & 2449 \\ 275 & 226 & 186 & 131 \\ 433 & 374 & 314 & 236 \\ 99 & 85 & 62 & 44\end{array}$

- 253

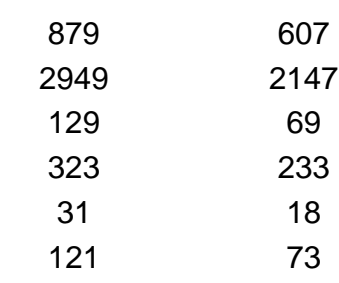

$\begin{array}{cc}126 & 195 \\ 150 & 264 \\ 95 & 116 \\ 36 & 59 \\ 64 & 69 \\ 57 & 71\end{array}$

cluster=1 -

$\overbrace{\mathbb{0}}^{\infty}$ cluster=2 -

这 cluster $=3-0$

$\begin{array}{ll}\text { Ė cluster=4 - } & 0 \\ \text { Oे cluster }=5 \text { - } & 0\end{array}$ b. TUEF/TULIP

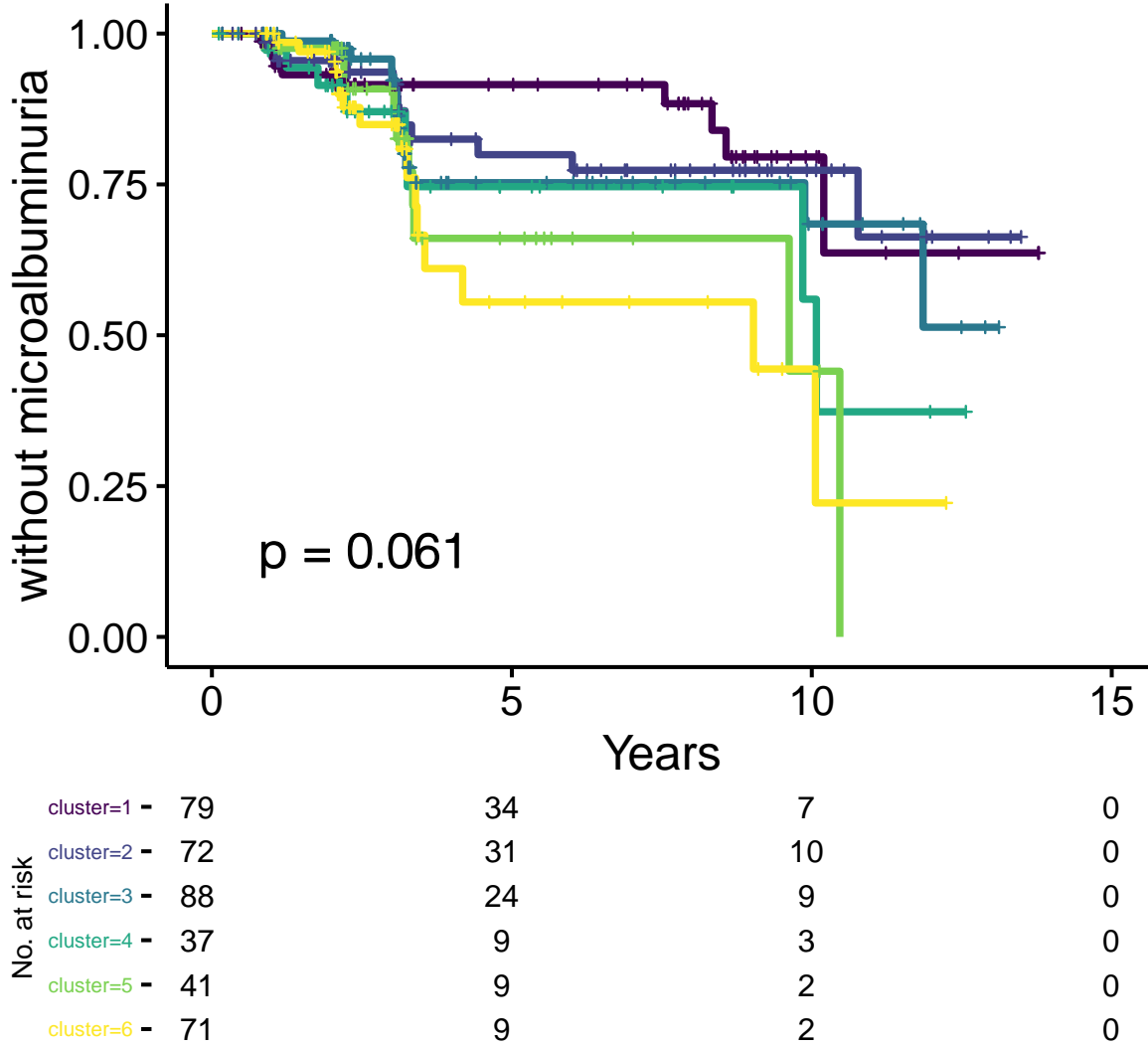

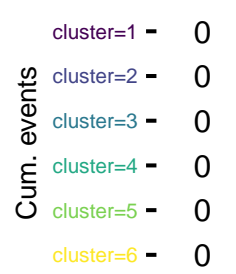

\section{d. Whitehall II}

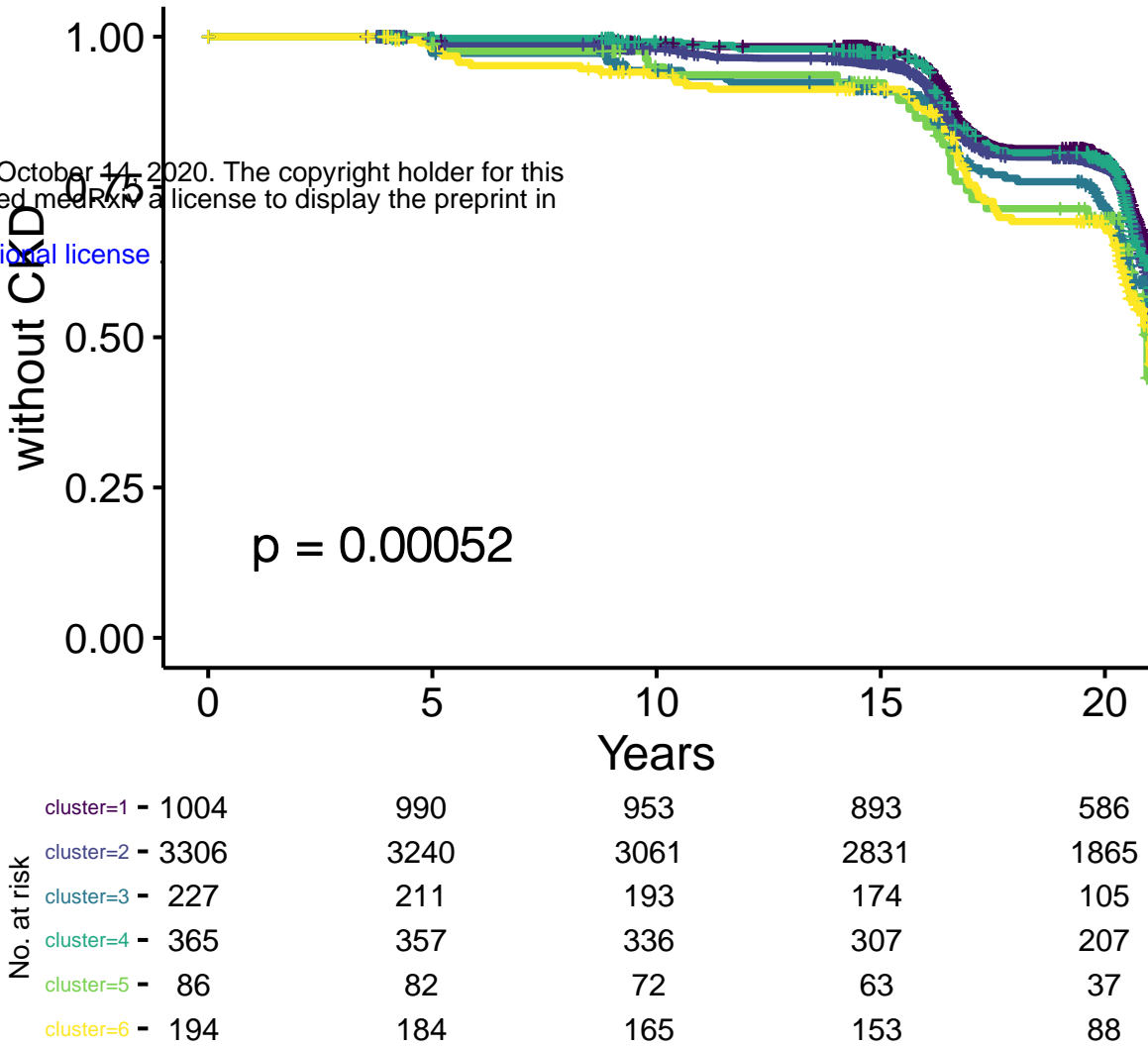

$\begin{array}{ccc}6 & 9 & 10 \\ 10 & 11 & 12 \\ 13 & 14 & 15 \\ 6 & 7 & 8 \\ 8 & 9 & 10 \\ 14 & 15 & 16\end{array}$

\section{f. Whitehall II}

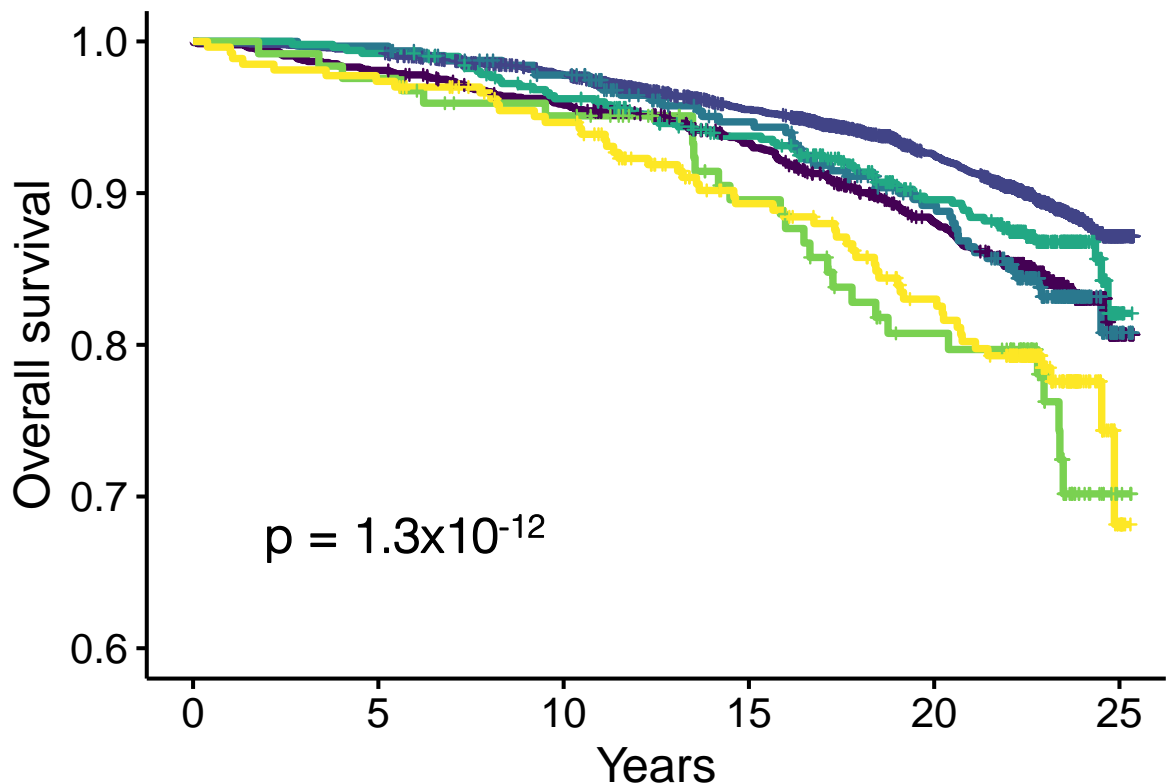

\begin{tabular}{|c|c|c|c|c|c|}
\hline cluster=1 - 1361 & 1335 & 1293 & 1214 & 1086 & 35 \\
\hline cluster=2 - 4224 & 4196 & 4076 & 3775 & 3383 & 148 \\
\hline$\frac{d}{2}$ cluster=3 - 322 & 321 & 303 & 267 & 229 & 12 \\
\hline cluster=4 - 507 & 503 & 480 & 446 & 385 & 8 \\
\hline$z_{\text {cluster }=5}-123$ & 120 & 114 & 95 & 76 & 4 \\
\hline cluster $=6-266$ & 259 & 243 & 205 & 178 & 8 \\
\hline
\end{tabular}

